$$
\begin{aligned}
& \text { तF } 50-10 \\
& 601853 \\
& 0071
\end{aligned}
$$

\title{
Affordability and Other Factors Affecting the Purchase of Energy-Efficient Manufactured Homes
}

\author{
M.P. Hattrup \\ A.D. Lee \\ L.J. Sandahl \\ S.A. Onisko(a)
}

June 1993

Prepared for the Bonneville Power Administration

under a Related Services Agreement with the U.S. Department of Energy

Contract Number DE-AC06-76RLO 1830

\footnotetext{
(a) Bonneville Power Administration,

Portland, Oregon
}

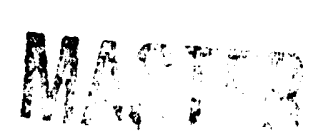




\section{SUMMARY}

The Pacific Northwest Laboratory (PNL) and the Bonneville Power Administration (Bonneville) conducted this study to evaluate the manufactured home owner's purchase decision process and to provide Bonneville with a better understanding of how consumers view a manufactured home's affordability and energy efficiency. This study addresses manufactured homes built under the U.S. Department of Housing and Urban Development (HUD) standards; these homes are sometimes referred to as HUD-code homes or mobile homes. Manufactured home owners in Idaho, Montana, Oregon, and Washington were included in this analysis.

This report adds to the information presented in Sandahi et al. (1992), which discussed the practices of lenders, appraisers, and dealers - all of whom play a key role in the manufactured home market due to the impact their practices have on the overall affordability of manufactured homes. This report focuses exclusively on the most important, and probably least understood, player - the home buyer.

Consurners' preferences and attitudes have a major effect on the manufactured home purchase decision. The objective of this study is to provide information that Bonneville and others in the Pacific Northwest can use to take buyers into account when designing and conducting programs that encourage energy-efficiency improvements in new, and used, manufactured homes. This study supports the regional Manufactured-Housing Acquisition Program (MAP) for new energy-efficient manufactured homes. It also should be useful to regional efforts to retrofit existing manufactured homes with energy-efficiency measures because of the extensive information presented on households living in used manufactured homes. The report may also be beneficial to program designers and implementers in other regions who recognize the need to improve manufactured housing energy efficiency.

The information in this report represents the first extensive primary data collected from manufactured home owners under Bonneville's manufactured housing program. The primary data were collected via a mail survey sent to 1,550 manufactured home owners in Idaho, Montana, Oregon, and Washington in late 1992. A $71 \%$ response rate was achieved; 1,106 usable responses were received. This study focuses on the Pacific Northwest but presents information that may be relevant to other parts of the country. 
The following issues and research questions are addressed in this study:

- Manufactured home buyer demographics: What are the basic demographic characteristics of manufactured home buyers in the Pacific Northwest? How do they differ by state?

- Manufactured home characteristics: What are the basic characteristics of homes purchased in the region?

- Factors in the purchase decision: What general factors influence the buyer's purchase decision and what is their relative importance? What house features influence the decision and what is their relative importance? How does the importance of these factors differ with the buyer and with home characteristics?

- Financing: What approaches do buyers use to finance their manufactured home purchase? How do financing approaches and terms vary with the buyer and home characteristics?

- Affordability: What factors do buyers believe deter!nine the affordability of a manufactured home and how important are these factors? How does the importance of these factors differ with buyer characteristics? How affordable are manufactured homes? What would make energy-efficient manufactured homes more affordable?

- Market segments: How can manufactured home buyers be segmented? What are the characteristics of buyers in the different market segments? How can geographic location and other segmentation characteristics be used to target programs for energy-efficient manufactured homes?

These issues are addressed specifically for buyers of new homes and used homes.

\section{KEY FINDINGS}

Heads of manufactured home households in the region had an average age of 53 years. Manufactured home owner ages are evenly distributed in three groups: under 40 , between 40 and 65 , and 65 years old or over. The average annual household income was $\$ 25,000$. In Montana and Idaho, the household heads tended to be younger and have less income than those in Oregon and Washington. 
Thirty-six percent of the manufactured homes purchased after 1984 were new and $64 \%$ were used homes. About half the new homes were sited on the owner's own land.

Regionally, electricity is the predominant heating fuel; electricity is used less in Idaho and Montana than in Oregon and Washington. Probably because of improved building practices, the occupant-estimated heating costs were about $\$ 100$ more per year for used homes than for new homes. Because nearly half the manufactured homes in the region were built before the HUD code, which established minimum efficiency standards, went into effect, a large potential exists for energy savings through energy-efficiency retrofits.

Seventy percent of new-home buyers financed their purchase through a new mortgage, while only $38 \%$ of used-home buyers did so; the remaining buyers usually paid cash for their homes. For new manufactured homes, a substantial share of retirees - about $67 \%$ - paid for them with cash. The loan terms for buyers who were buying both the home and the land together were not significantly different from the terms on loans to buyers for the home only. Lending practices differ notably from state to state.

Of the general factors affecting the purchase decision, affordability has the most influence. This is especially true of younger households who have not had as long to accumulate savings. Considering home physical features and amenities, the one that had the most influence for new-home buyers was the number of windows or window area, followed by an efficient heating and cooling system. The desire for efficient heating/cooling systems is important to energy-efficiency programs.

The primary determinant of economic affordability is generally the home's total purchase price. Buyers, particularly buyers of new manufactured homes, also consider current utility bills and long-term heating and cooling costs to be very important in determining affordability, thus making them good targets for energyefficiency programs. New-home buyers also rate energy-efficiency features (added insulation, efficient windows, etc.) as far more influential in their purchase decision than used-home buyers do. Because energy-efficiency and related factors are less important in the purchase decision of used-home buyers, energy-efficiency retrofit programs may be more difficult to market than programs targeted at new homes.

Study data were used to evaluate the affordability of energy-efficient manufactured homes. An important finding is that the typical buyer of an energyefficient manufactured home who finances the land and home together should easily 
be able to qualify for a loan, even without lenders modifying ("stretching") the housing expense/income ratio to take the reduced utility bills into account. In addition, buyers do not consider the lending qualification ratio to be very important in their decision to purchase a home, thus raising questions about the effectiveness of energy-efficient mortgages that stretch the qualification ratio.

There are important differences in the characteristics of different groups of buyers. Buyers can be segmented according to their life-cycle characteristics (i.e., employment status, number of family members, age, etc.). Twelve manufactured housing market segments are defined that can be used for program targeting purposes. The single largest market segment in the Pacific Northwest is young families, comprising $23 \%$ of manufactured home owners. The market segment information, along with geographic location (state or television marketing area), type of home purchased (new or used), and type of loan (e.g., home/only or home/land) could be used to design future regional programs. 


\section{CONTENTS}

SUMMARY $\ldots \ldots \ldots \ldots \ldots \ldots \ldots \ldots \ldots \ldots \ldots \ldots \ldots \ldots \ldots \ldots$ iii

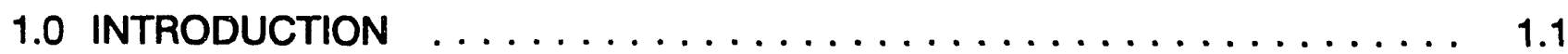

1.1 BACKGROUND $\ldots \ldots \ldots \ldots \ldots \ldots \ldots \ldots \ldots \ldots \ldots \ldots \ldots \ldots$

1.2 SCOPE OF STUDY $\ldots \ldots \ldots \ldots \ldots \ldots \ldots \ldots \ldots \ldots$

1.3 SURVEY AND SAMPLE DESCRIPTIONS $\ldots \ldots \ldots \ldots \ldots \ldots \ldots$

1.4 ORGANIZATION OF THE REPORT $\ldots \ldots \ldots \ldots \ldots \ldots \ldots \ldots \ldots$

2.0 GENERAL STATISTICS FOR THE MANUFACTURED HOME BUYER . . . . 2.1

2.1 REGIONAL AND STATE-BY-STATE HOME BUYER PROFILES $\ldots \ldots \quad 2.1$

2.1.1 Demographic and Manufactured Home Stock Comparisons . 2.1

2.1.2 Comparison of Financial Factors and Lending Practices . . . $\quad 2.2$

2.1.3 Comparison of Heating Fuel Usage and Costs $\ldots \ldots \ldots .2 .4$

2.1.4 General Purchase Factors: Regional Results and State Comparisons ..................... 2.5

2.1.5 Factors Determining Affordability: Regional and State Results ..................... 2.5

2.1.6 Home Feature Influences: Regional and State Results . . . . 2.8

2.2 NEW AND USED MANUFACTURED HOME PURCHASER PROFILES 2.9

2.2.1 Demographic and Manufactured Home Stock Comparisons . 2.10

2.2.2 Comparison of Financial Factors and Lending Practices . . . 2.10

2.2.3 Heating Fuel and Costs for New- and Used-Home Buyers . . 2.12 
2.2.4 Additional Comparisons of New- and Used-Home Buyers . . 2.13

2.2.5 The Influence of General Purchase Factors: New- and Used-Home Buyers . . . . . . . . . . . . . . 2.15

2.2.6 Factors Determining Affordability: New- and Used-Home

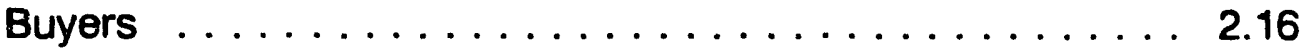

2.2.7 Home Feature Influences: New- and Used-Home Buyers . . 2.18 3.0 STATISTICS FOR HOME-LAND PURCHASES AND HOME-ONLY

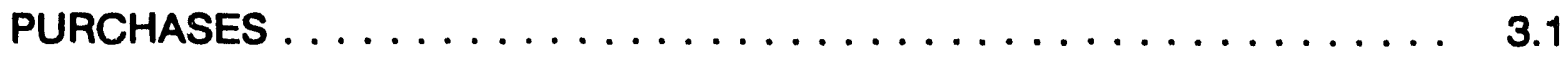

3.1 DEMOGRAPHIC PROFILES OF HOME-LAND AND HOME-ONLY PURCHASERS $\ldots \ldots \ldots \ldots \ldots \ldots \ldots \ldots \ldots \ldots \ldots \ldots \ldots \ldots$

3.1.1 Implications from the Demographic Profiles . . . . . . . 3.4

3.1.2 Additional Comparisons Between Home-Land and HomeOnly Purchasers . . . . . . . . . . . . . . . . . . . 3.5

3.2 FACTORS AFFECTING HOME-LAND AND HOME-ONLY

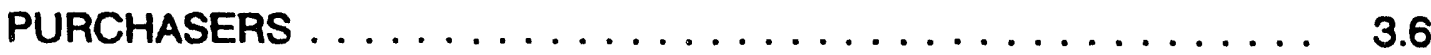

3.2.1 The Influence of General Purchase Factors . . . . . . . . 3.6

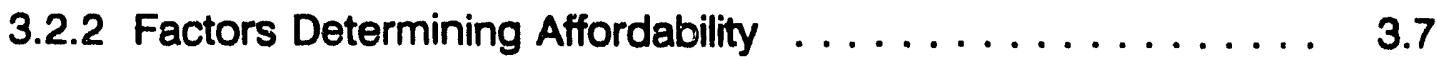

3.2.3 Home Feature Influences . . . . . . . . . . . . . . . 3.9

3.2.4 The Role of Energy Efficiency $\ldots \ldots \ldots \ldots \ldots \ldots \ldots . . \ldots 3.10$

4.0 SEGMENTATION APPROACHES $\ldots \ldots \ldots \ldots \ldots \ldots \ldots \ldots \ldots \ldots . \ldots \ldots$

4.1 LIFE-CYCLE SEGMENTATION $\ldots \ldots \ldots \ldots \ldots \ldots \ldots \ldots \ldots . .1$

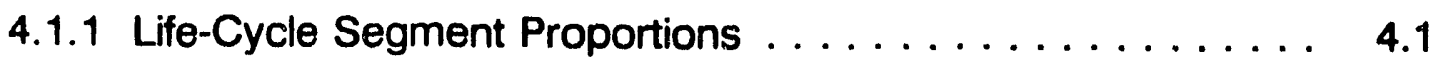

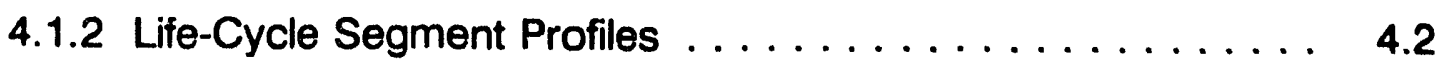


4.1.3 Preliminary Analysis of the Life-Cycle Segments $\ldots \ldots \ldots \quad 4.5$

4.2 SEGMENTATION BY AREA OF DOMINANT INFLUENCE (ADI) . . . . 4.6

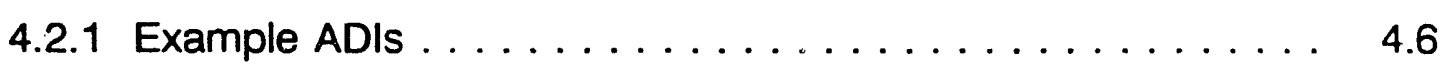

4.2.2 Demonstration of ADI-Based Segmentation . . . . . . 4.7

5.0 HOME OWNER PERCEPTIONS OF AFFORDABILITY . . . . . . 5.1

5.1 AFFORDABILITY CORRELATION ANALYSIS $\ldots \ldots \ldots \ldots . \ldots \ldots$

5.2 AFFORDABILITY'S INFLUENCE ACROSS LIFE-CYCLE SEGMENTS . 5.2

6.0 ENERGY-EFFICIENT MANUFACTURED HOME AFFORDABILITY INDEX . . . 6.1

6.1 REVIEW OF MANUFACTURED HOUSING AFFORDABILITY

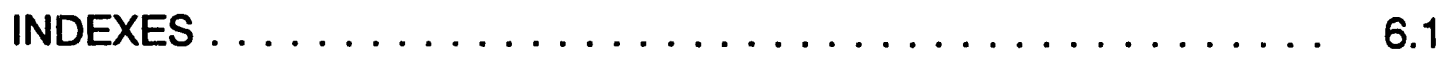

6.2 SURVEY RESULTS AND THE AFFORDABILITY INDEXES $\ldots \ldots \ldots 6.2$

6.3 KEEPING ENERGY-EFFICIENT HOMES AFFORDABLE $\ldots \ldots \ldots .6 .3$

7.0 FINDINGS AND CONCLUSIONS $\ldots \ldots \ldots \ldots \ldots \ldots \ldots \ldots \ldots \ldots \ldots$

7.1 OCCUPANT CHARACTERISTICS $\ldots \ldots \ldots \ldots \ldots \ldots \ldots \ldots . \ldots \ldots$

7.2 MANUFACTURED HOME CHARACTERISTICS $\ldots \ldots \ldots \ldots \ldots .2$

7.3 FACTORS IN THE PURCHASE DECISION $\ldots \ldots \ldots \ldots \ldots \ldots$

7.4 FINANCING THE PURCHASE OF MANUFACTURED HOMES . . . . . 7.4

7.5 AFFORDABILITY OF MANUFACTURED HOMES $\ldots \ldots \ldots \ldots . . \ldots$

7.6 MARKET SEGMENTS $\ldots \ldots \ldots \ldots \ldots \ldots \ldots \ldots \ldots$

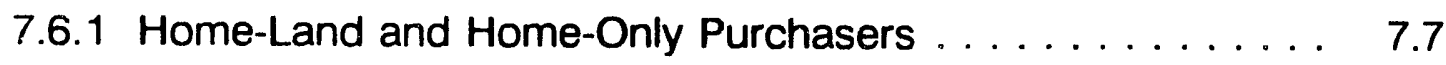

7.6.2 Life-Cycle Market Segments $\ldots \ldots \ldots \ldots \ldots \ldots \ldots .7 .7$ 
8.0 RECOMMENDATIONS $\ldots \ldots \ldots \ldots \ldots \ldots \ldots \ldots \ldots \ldots \ldots \ldots .1$

8.1 UPGRADING THE EFFICIENCY OF EXISTING MANUFACTURED

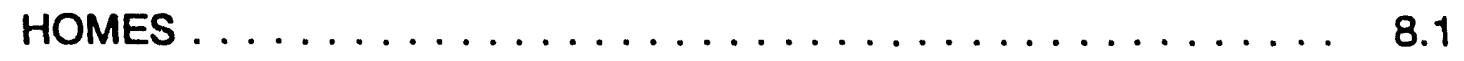

8.2 LENDING PRACTICES $\ldots \ldots \ldots \ldots \ldots \ldots \ldots \ldots \ldots \ldots \ldots .2$

8.3 PROGRAM ACTIONS $\ldots \ldots \ldots \ldots \ldots \ldots \ldots \ldots \ldots .3$

8.4 RESEARCH NEEDS $\ldots \ldots \ldots \ldots \ldots \ldots \ldots \ldots \ldots \ldots \ldots .4$

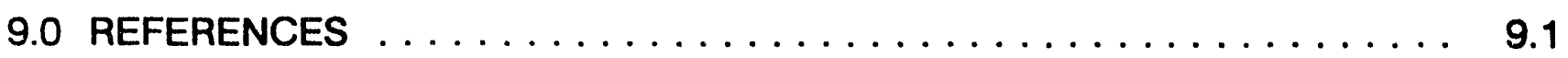

APPENDIX A - LIFE-CYCLE SEGMENT DEVELOPMENT $\ldots \ldots \ldots \ldots \ldots \ldots$ A.1 


\section{TABLES}

1.1 Sample Structure and Usable Responses $\ldots \ldots \ldots \ldots \ldots \ldots \ldots \ldots$

2.1 Region and State Household Head's Age Distribution $\ldots \ldots \ldots \ldots \ldots 2.2$

2.2 Region and State Mean General Purchase Factor Influence Ratings . . . . 2.6

2.3 Region and State Mean Economic Affordability Fastor Influence Ratings . $\quad 2.7$

2.4 Region and State Mean Home Feature Influence Ratings $\ldots \ldots \ldots \ldots$

2.5 New and Used Home Buyer Household Head's Age Distribution . . . . . . 2.10

2.6 Average Loan Features Comparison, New- and Used-Home Buyers . . . 2.12

2.7 Manufactured Home Siting Distribution $\ldots \ldots \ldots \ldots \ldots \ldots \ldots \ldots$

2.8 New- and Used-Home Buyers' Mean General Purchase Factor Influence

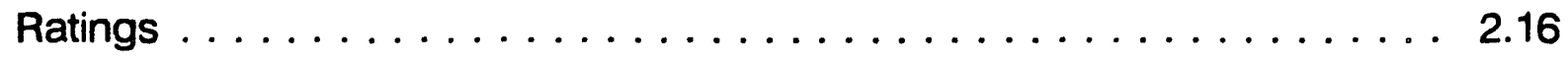

2.9 New- and Used-Home Buyers' Mean Affordabilitj Factor Influence Ratings . . . . . . . . . . . . . . . . . . . . . . 2.17

2.10 New- and Used-Home Buyers' Mean Home Feature Influence Ratings ${ }^{(a)} \ldots 2.18$

3.1 Home-Lands and Home-Onlys Head of Household Age Distribution . . . . 3.2

3.2 Household Size Distributions for Home-Lands and Home-Onlys . . . . . . 3.2

3.3 Household Heads Employment Status for Home-Lands and Home-Onlys . $\quad 3.3$

3.4 Types of Families in the Home-Onlys and Home-Lands $\ldots \ldots \ldots \ldots$

3.5 Home-Land and Home-Only Household Income Distribution . . . . . . 3.4

3.6 Loan Term Comparison of Home-Lands and Home-Onlys . . . . . . . . 3.4 
3.7 Home-Land and Home-Only Mean General Purchase Factor Influence Ratings . . . . . . . . . . . . . . . . . . . . . . 3.7

3.8 Home-Land and Home-Only Mean Economic Affordability Factor

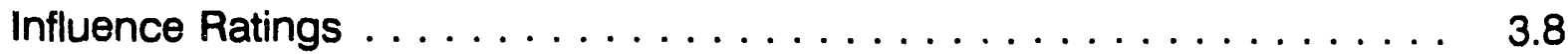

3.9 Comparison of Mean Home Feature Influence Ratings . . . . . . . . . 3.10

4.1 Relative Proportions of Life-Cycle Segments . . . . . . . . . . . . . 4.2

4.2 Relative Proportions of ADls $\ldots \ldots \ldots \ldots \ldots \ldots \ldots \ldots \ldots \ldots$

6.1 Home-Land Affordability Index Values . . . . . . . . . . . . . . 6.4

A.1 Values for Variables FEMP and MEMP $\ldots \ldots \ldots \ldots \ldots \ldots \ldots \ldots$ A.1

A.2 Creation of the Variable WORK $\ldots \ldots \ldots \ldots \ldots \ldots \ldots \ldots$

A.3 Values and Definitions for the Variable WORK ............. 2

A.4 Values and Definitions for the Variable HAGE .............. 3

A.5 Values and Definitions for the Variable LC ... . . . . . . . . . 4 


\subsection{INTRODUCTION}

The impact of energy conservation measures (ECMs) on the affordability of HUD-code manufactured homes is a concern of those involved in the manufactured housing industry. HUD-code manufactured homes are built under national standards established by the U.S. Department of Housing and Urban Development (HUD) that went into effect in 1976. ECMs increase the construction costs of manufactured homes making the homes more expensive and, some people would argue, less affordable to consumers. The Pacific Northwest Laboratory (PNL) prepared this report for the Bonneville Power Administration (Bonneville), in part to address the role of affordability in the manufactured home buyer's purchase decision. The objective of this study is to provide preliminary information that Bonneville and others in the Pacific Northwest can use to take buyers into account in continuing efforts to design and conduct programs that encourage energy-efficiency improvements in new, and used, manufactured homes. This report will be particularly useful to anticipate market responses once Bonneville's current Manufactured-Housing Acquisition Program (MAP) is completed in 1995.

Affordability has been a concern since organizations throughout the United States started examining ways to increase the energy efficiency of manufactured homes. Because manufactured homes are less expensive to buy than comparable site-built homes, they have appealed to lower-income buyers. As energy costs have risen, however, the lower energy efficiency of many manufactured homes has made them expensive to heat and cool and, therefore, expensive to own and operate. Bonneville and others in the Pacific Northwest have made a major commitment to improve the energy efficiency of new manufactured homes and have had to address head on the buyer impacts of higher purchase prices that may be required to achieve substantial energy savings and lower operating costs. Similar concerns arise in programs to improve the energy efficiency of existing manufactured homes. This report addresses affordability issues that will continue to arise as the Pacific Northwest moves into the next phase of a regional energy-efficient manufactured home program. For the longer run and for other regions, this report provides a foundation for understanding how the marketplace accommodates energy efficiency improvernents in manufactured homes. 


\subsection{BACKGROUND}

The Pacific Northwest is currently leading the nation in the construction of HUDcode manufactured homes that are significantly more energy efficient than HUD requires. Bonneville's Super Good Cents (SGC) program, instituted in 1985 as a means to improve the efficiency of new site-built homes, was expanded to include manufactured homes in 1989. By 1990, all 18 of the rejion's manufacturing plants were participating in the program. Under the SGC program, Bonneville paid consumers an incentive of about $\$ 2,000$ to offset the higher cost of the home. In return, Bonneville's service region (Oregon, Washington, Idaho, and parts of Montana) realized a space heating energy savings per home of about $50 \%$ and home owners enjoyed lower utility bills.

Although substantial energy savings were realized from the SGC program, only $30 \%$ of manufactured home buyers purchased SGC homes. In an effort to expand upon the success of the SGC program and reach a larger proportion of the region's manufactured home buyers, Bonneville, the investor-owned and public utilities, and the region's manufacturers, reached an agreement designed to ensure that all electrically heated homes built in the Northwest meet stringent energy-efficiency requirements. This program, called the Manufactured-Housing Acquisition Program or MAP, requires participating manufacturers to build $100 \%$ of their electrically heated homes to the program's high efficiency levels. Utilities pay each manufacturer $\$ 2,500$ per MAP home built.

The MAP replaced the SGC program in April 1992 and will run for 4 years. MAP energy-efficiency requirements are even stiffer than the previous SGC requirements. The new specifications are expected to deliver average savings of $6,000 \mathrm{kWh}$ yearly per home, versus $4,000 \mathrm{kWh}$ yearly per home under SGC. The MAP begins a new chapter in the region's efforts to promote energy efficiency.

Even though $100 \%$ of the region's electrically heated manufactured homes are being built to stringent energy-efficiency specifications under MAP, Bonneville realizes the importance of understanding and investigating the dynamics of the manufactured housing market and what factors influence the demand for energy-efficient manufactured homes. Although most of the increased material cost required to meet MAP energy-efficiency requirements is offset by the incentive payment, MAP homes may cost consumers more money than standard HUD-code homes. Bonneville's desire to better understand certain aspects of the manufactured housing market, including affordability, is the basis for this report. 


\subsection{SCOPE OF STUDY}

PNL collected and evaluated primary data on manufactured home purchasers for Bonneville to enhance understanding of the purchase decision process.

The following issues and research questions are addressed in this study:

- Manufactured home buyer demographics: What are the basic demographic characteristics of manufactured home buyers in the Pacific Northwest? How do they differ by state?

- Manufactured home characteristics: What are the basic characteristics of manufactured homes purchased in the region?

- Factors in the purchase decision: What general factors influence the buyer's purchase decision and what is their relative importance? What house features influence the decision and what is their relative importance? How does the importance of these factors differ with the buyer and home characteristics?

- Financing: What approaches do buyers use to finance their manufactured home purchase? How do financing approaches and terms vary with the buyer and home characteristics?

- Affordability: What factors do buyers believe determine the affordability of a manufactured home and how important are these factors? How does the importance of these factors differ with buyer characteristics? How affordable are manufactured homes? What would make energy-efficient manufactured homes more affordable?

- Market segments: How can manufactured home buyers be segmented? What are the characteristics of buyers in the different market segments? How can geographic location and other segmentation characteristics be used to target programs for energy-efficient manufactured homes?

These issues are addressed specifically for buyers of new homes and used homes. 


\subsection{SURVEY AND SAMPLE DESCRIPTIONS}

The data presented in this report were collected from a sample of 1,550 manufactured home owners in Idaho, Montana, Oregon, and Washington via a mail survey conducted in late 1992. The sample was drawn to match the relative proportions of new manufactured home shipments in the four states from 1985 to 1991 as reported by the National Conference of States on Building Codes and Standards, Inc. (NCSBCS).

Shipment data were used to determine the sample proportions. The survey focused on buyers who had purchased their homes since 1984 to improve the quality and timeliness of the data obtained. The post- 1984 shipment data indicated $48.7 \%$ of the new manufactured homes shipped into the four states were located in Washington, about $6.1 \%$ were shipped to Montana, $8.4 \%$ went to Idaho, and $36.8 \%$ were shipped to Oregon. The sample proportions were relatively close to the shipment proportions. A $71 \%$ response rate was achieved as 1,106 usable responses were received from the 1,550 sample households. Table 1.1 contains the number of households included in the sample (by state), the number of usable responses received (by state), and the $S$ :e-specific and overall response rates.

TABLE 1.1. Sample Structure and Usable Responses

\begin{tabular}{|l|r|r|r|r|r||}
\hline & WA & OR & ID & MT & Total \\
\hline \hline No. and \% of & 33,637 & 25,469 & 5,838 & 4,196 & 69,140 \\
$1985-91$ New Home Shipments & $48.7 \%$ & $36.8 \%$ & $8.4 \%$ & $6.1 \%$ & $100.0 \%$ \\
\hline No. and \% of Homes in Sample & 755 & 570 & 130 & 95 & 1,550 \\
& $48.7 \%$ & $36.8 \%$ & $8.4 \%$ & $6.1 \%$ & \\
\hline No. and \% of Usable & 546 & 413 & 83 & 64 & 1,106 \\
Responses & $49.4 \%$ & $37.3 \%$ & $7.5 \%$ & $5.8 \%$ & \\
\hline Response Rate & $72 \%$ & $72 \%$ & $64 \%$ & $67 \%$ & $71 \%$ \\
\hline
\end{tabular}

The survey included responses from purchasers of both new and used manufactured homes before and after the end of 1984. Used-home buyers were included in the analysis to provide information that may be useful for regional retrofit programs and for comparison with buyers of new manufactured homes. Typically the 
analysis supporting each of the chapters and some of the sections within the chapters did not include the entire sample. A commonly used subset of responses are from those who purchased their home after 1984. In instances when a section's results do not rely on the responses of the entire sample, the relevant subgroup will be identified at the beginning of the section.

\subsection{ORGANIZATION OF THE REPORT}

Chapter 2 contains a discussion of region-wide and state-by-state descriptions of manufactured home owners. It also compares purchasers of new and used manufactured homes; this information should be useful in designing and implementing regional retrofit programs. Chapter 3 contains a comparison of manufactured home purchasers who have placed the home on their own private property with those who have their homes located on someone else's property. Chapter 4 contains a discussion of a market segmentation approach involving life-cycle segments based on demographic data; Chapter 4 also includes an examination of the usefulness of "Area of Dominant Influence" (ADI) data to Bonneville. Chapter 5 discusses how home owners themselves think of affordability. Chapter 6 contains a discussion on the affordability index and how it might be modified for Bonneville's service territory. Chapter 7 discusses the findings and conclusions based on the results of the analysis. Chapter 8 discusses the implications of the findings and conclusions for Bonneville. Chapter 9 contains references. 


\subsection{GENERAL STATISTICS FOR THE MANUFACTURED HOME BUYER}

The first section in this chapter presents information about the manufactured home buyer on a region-wide basis and a state-by-state basis. The second section compares purchasers of new and used manufactured homes. Both sections include information regarding certain demographic variables, loan terms, and heating fuel use and costs. The sections also include a discussion of the influence several general purchase factors (e.g., affordability, energy efficiency, aesthetic appeal, etc.) can have on the purchase decision. "Affordability" was included as one of the general factors for respondents to assess. The term was not defined for the respondents, but their answers to subsequent questions about costs of owning a manufactured home allowed us to determine what factors they thought determined affordability. The sections discuss the influences of these factors (e.g., total purchase price, interest rate on the mortgage, monthly utility bills, etc.) on the home buyer's determination of whether they could afford their manufactured home. Finally, they present information on the influence different home features or options (e.g., number of windows/window area, additional insulation, painted and textured drywall, etc.) can have on the home buyer's purchase decision.

\subsection{REGIONAL AND STATE-BY-STATE HOME BUYER PROFILES}

This section provides information on home buyers for the entire region and for each state. The following sections contain discussions regarding certain demographic variables $^{(a)}$, typical loan terms, heating fuel usage and cost, among other items. The data in this section are for those who have purchased a new or used home since the end of 1984. About half the survey respondents purchased their homes after 1984.

\subsubsection{Demographic and Manufactured Home Stock Comparisons}

The head of the household's average age was 53; the average age for Washington was 56, for Oregon it was 57, for Idaho it was 35, and for Montana it was 44. Table 2.1 contains the age distribution (by quantile) for the region and each state.

(a) Complete manufactured home household demographic data were available from the survey, but only selected statistics are reported here. The discussion of life-cycle segments in Chapter 4 reflects other demographic statistics. 
It is apparent that Idaho has the youngest population of manufactured home owners while Oregon has the oldest population. This is consistent with Sandahl et al. (1992).

TABLE 2.1. Region and State Household Head's Age Distribution

\begin{tabular}{|c|c|c|c|c|c||}
\hline Percentile & $\begin{array}{c}\text { Region- } \\
\text { Wide Age } \\
\text { Dist. }\end{array}$ & $\begin{array}{c}\text { Washington } \\
\text { Age Dist. }\end{array}$ & $\begin{array}{c}\text { Oregon } \\
\text { Age Dist. }\end{array}$ & $\begin{array}{c}\text { Idaho } \\
\text { Age } \\
\text { Dist. }\end{array}$ & $\begin{array}{c}\text { Montana } \\
\text { Age Dist. }\end{array}$ \\
\hline $100 \%$ & 91 & 91 & 89 & 80 & 88 \\
\hline $75 \%$ & 69 & 69 & 74 & 55 & 61 \\
\hline $50 \%$ (Median) & 53 & 59 & 66 & 43 & 46 \\
\hline $25 \%$ & 37 & 43 & 47 & 33 & 37 \\
\hline $0 \%$ & 22 & 20 & 24 & 23 & 24 \\
\hline
\end{tabular}

The median purchase year for the region was 1988, and varied little by state. About one-fourth of the manufactured homes purchased in the region since 1984 were built in 1974 or earlier. This information suggests that a significant proportion of manufactured homes are pre-HUD-code vintage. Each time one of these older homes is purchased instead of a newer more efficient home it represents a lost conservation opportunity for Bonneville and the region's utilities. It is likely that those who opt to purchase one of these older homes do so because of their comparatively low purchase cost.

\subsubsection{Comparison of Financial Factors and Lending Practices}

The responses of those who had purchased their home after the end of 1984 were used to determine the median income at the time of purchase for the region and for each state. These data can provide Bonneville with at least a feel for the relative income levels within the four states.

For these buyers who had purchased their home after 1984, the median household income at the time the manufactured home was purchased was $\$ 25,000$ for the entire region. In Washington and Oregon the median income was $\$ 25,000$, in Idaho it was $\$ 17,000$, and in Montana it was $\$ 20,000$. The median loan amount at the time of purchase was $\$ 25,500$ for the region; it was $\$ 28,500$ for Washington, $\$ 25,000$ 
for Oregon, $\$ 18,563$ for Idaho, and $\$ 18,250$ for Montana. Because manufactured home owners in Idaho and Montana are less affluent, manufactured home sales in these two states are likely to be more affected if manufactured home prices rise as a result of the added costs of ECMs.

The respondents who took out loans were asked about whether the dealer arranged their financing, how many lenders they contacted, the term of their loan, the down payment, the current interest rate, and the interest rate at the loan's origination date. Dealers arranged a loan or recommended the lender to $49 \%$ of all buyers. For new-home buyers only, almost $72 \%$ had their loan arranged by the dealer or the dealer recommended a lender. For used-home buyers, the comparable figure was only $29 \%$. For all buyers securing a loan, $36 \%$ arranged their own loan without the dealer's direct involvement. Only $26 \%$ of new-home buyers arranged their own loan, whereas $45 \%$ of used-home buyers did so.

Of the buyers who arranged their own loans, less than $10 \%$ contacted three or more lenders. The median loan term for the region was 15 years; this was also the median loan term in Washington and Oregon. However, the median loan term was only 10 years in Idaho and only 8 years in Montana. The region's median down payment was $10 \%$; this was also the case in each state except Montana where the median down payment was $12 \%$. The current median interest rate on manufactured home loans in the region was $10.9 \%$. In Washington it was $11 \%$, while in Oregon and Idaho it was $10 \%$, and in Montana it was $12 \% .{ }^{\text {(a) }}$ The higher rate in Montana was probably the result of the smaller loan amounts and the shorter terms. Based on this information, different lending terms may face manufactured home buyers in each state; thus, state-specific affordability calculations may be necessary.

The respondents were also asked about the amount of their current principal and interest payments, their monthly lot/rent fees, their monthly property taxes, and their monthly home-owner insurance payments. The median principal and interest payment for the region was $\$ 304$; Washington's was higher than average at $\$ 338$, while Idaho's was lower than average at $\$ 215$. The median monthly lot rent for the region was $\$ 185$; in Washington it was $\$ 193$, in Oregon it was $\$ 210$, in Idaho it was

(a) Because the survey data represent statistics from several years, the results are more reliable for indicating trends or differences than precise estimates of values, such as interest rates. This report focuses on highlighting trends and differences across states or groups of buyers. The reader should keep this in mind in interpreting the values presented here. 
$\$ 120$, and in Montana it was $\$ 125$. The median monthly property tax payment for the region was $\$ 46$; in Washington it was $\$ 40$, and in Oregon it was $\$ 67$. It was under $\$ 30$ in Idaho and Montana. This information also suggests that separate home-only affordability calculations should be made for each state. However, because there were only a small number of home-only respondents from Idaho and Montana, additional data would be needed before accurate indices could be developed for those states.

\subsubsection{Comparison of Heating Fuel Usage and Costs}

The manufactured home owners were also asked about their primary heating fuel, their average monthly utility bills, and an estimate of their annual heating cost. The primary heating fuel results presented here are based on what the occupant corisiders to be the fuel they use most for heating. However, the reader should note that the HUD code requires all new manufactured homes to have a conventional heating system installed. Thus, for home owners who consider wood to be their primary heating fuel, they are very likely to have an electric or gas heating system installed and it may be used to meet a large share of their heating needs.

Approximately $66 \%$ of the manufactured homes in the region use electricity as their primary heating fuel, $21 \%$ use wood, about $10 \%$ use natural gas, and $3 \%$ use propane. In Washington, $76 \%$ heat with electricity, $18 \%$ heat with wood, $3 \%$ heat with gas, and $2 \%$ heat with propane. In Oregon, $65 \%$ of the homes heat with electricity, $24 \%$ heat with wood, $7 \%$ heat with gas, and $3 \%$ use propane. In Idaho, $43 \%$ heat with electricity, $25 \%$ heat with wood, $27 \%$ heat with gas, and $4 \%$ heat with propane. In Montana only $17 \%$ heat with electricity, $63 \%$ heat with gas, $17 \%$ heat with wood, and $4 \%$ heat with propane. (Percentages may not add to 100 due to rounding.)

In the region, $68 \%$ of the homes use a central forced-air furnace as their primary heating system. Sixteen percent of the homes use a wood burning unit of some sort and $13 \%$ use a heat pump. ${ }^{(0)}$ The majority of homes in the region and each of the states use a central forced-air furnace as their primary heating system. Heat pumps had made the largest market penetration in Oregon where $18 \%$ of the

(a) It is possible that the share of homes with heat pumps is overstated. Home owners are not always certain about whether they have a heat pump. Because no questions were asked in the survey to confirm that the respondent understood the difference between heat pumps and other heating systems, the statistics presented in this report on heat pumps should be considered with some caution. 
households identified a heat pump as their primary heating system. None of the Montana and only $5 \%$ of the Idaho households in the study had a heat pump. Based on this information, heat pumps do not appear to meet with much customer acceptance in Idaho and Montana where the winter temperatures are likely to drop below a heat pump's effective operating range.

The average annual cost to heat a manufactured home in the region was $\$ 630$ based on home-owner estimates. Washington residents had the highest average annual heating cost at $\$ 684$, followed by those in Montana at $\$ 636$, Idaho at $\$ 632$, and finally Oregon at $\$ 601$.

\subsubsection{General Purchase Factors: Regional Results and State Comparisons}

This section and Sections 2.1.5 and 2.1.6 contain discussions of the mean influence ratings various factors and features had on the home buyers' purchase decision.

The respondents were asked to think back to the purchase of their current manufactured home and rate the influence each of the following factors had on their purchase decision: floor plan/layout, size, quality of construction, energy efficiency, aesthetic appeal, affordability, location, and amenities. For the remainder of the report these factors will be referred to as the general purchase factors. These factors were rated on a 7-point scale where $1=$ "No Influence" and $7=$ "Strong Influence. ${ }^{\text {"(a) }}$

Tabie 2.2 contains the region-wide and state-by-state mean influence ratings for each of the general factors. Of the general purchase factors, affordability had the highest average influence rating, both at the regional level and across the four states. The size of the home and the floor plan were the second and third most influential general purchase factors, respectively, at the regional level. This was also the case in all the state populations. On a regional basis the fourth most influential factor was the quality of construction.

A home's energy efficiency, by itself, was not very influential relative to the other general purchase factors. However, results in the following sections suggest that buyers do take energy efficiency and energy-efficient features into account in assessing affordability, which has the dominant influence on the purchase decision.

(a) This rating scale was also used for the economic affordability factors and the home features. 


\subsubsection{Factors Determining Affordability: Regional and State Results}

The respondents were asked to think back to the purchase of their current manufactured home and to rate how much influence each of the following factors had

TABLE 2.2. Region and State Mean General Purchase Factor Influence Ratings ${ }^{(a)}$

\begin{tabular}{||l|c|c|c|c|c||}
\hline $\begin{array}{l}\text { General Purchase } \\
\text { Factors }\end{array}$ & $\begin{array}{c}\text { Region- } \\
\text { Wide } \\
\text { Mean }\end{array}$ & $\begin{array}{c}\text { Washington } \\
\text { Mean }\end{array}$ & $\begin{array}{c}\text { Oregon } \\
\text { Mean }\end{array}$ & $\begin{array}{c}\text { Idaho } \\
\text { Mean }\end{array}$ & $\begin{array}{c}\text { Montana } \\
\text { Mean }\end{array}$ \\
\hline Affordability & 6.32 & 6.39 & 6.25 & 6.29 & 6.04 \\
\hline Home Size & 5.56 & 5.60 & 5.63 & 4.97 & 5.45 \\
\hline Floor Plan & 5.49 & 5.63 & 5.51 & 4.95 & 4.79 \\
\hline Construction Quality & 4.99 & 5.23 & 4.88 & 4.53 & 4.29 \\
\hline Location & 4.65 & 4.56 & 4.84 & 4.42 & 4.36 \\
\hline Aesthetic Appeal & 4.64 & 4.78 & 4.61 & 4.46 & 3.68 \\
\hline Energy Efficiency & 4.62 & 4.83 & 4.43 & 4.52 & 4.12 \\
\hline Amenities & 4.33 & 4.41 & 4.43 & 4.00 & 3.18 \\
\hline (a) 1 = "No Influence," $7=$ "Strong Influence." & & \\
\hline
\end{tabular}

in determining whether they could afford their home. The factors included the interest rate on the mortgage/loan, the down payment, the total purchase price, the length of the mortgage/loan, the expected maintenance costs for the home, the home's longterm heating and cooling costs, the monthly utility bills, the likely resale value, and finally lot/park fees. For the remainder of the report these factors will be referred to as the economic affordability factors. The mean scores for each of the economic affordability factors are presented in Table 2.3. ${ }^{(\mathrm{a})}$

Of particular interest are the comparisons of the region-wide and state-by-state mean influence scores for these economic affordability factors. On a region-wide

(a) This and subsequent tables present the results ranked from most to least influential at the regional level. 
basis, the most influential factor in determining whether a home was affordable was the home's total purchase price. This was also the case in each of the states. Except for total purchase price, the state populations did not respond uniformly. At the regional level the second most influential economic factor was the utility bill, followed

TABLE 2.3. Region and State Mean Economic Affordability Factor Influence Ratings ${ }^{(2)}$

\begin{tabular}{||l|c|c|c|c|c||}
\hline \hline $\begin{array}{l}\text { Economic Affordability } \\
\text { Factors }\end{array}$ & $\begin{array}{c}\text { Region- } \\
\text { Wide } \\
\text { Mean }\end{array}$ & $\begin{array}{c}\text { Washington } \\
\text { Mean }\end{array}$ & $\begin{array}{c}\text { Oregon } \\
\text { Mean }\end{array}$ & $\begin{array}{c}\text { Idaho } \\
\text { Mean }\end{array}$ & $\begin{array}{c}\text { Montana } \\
\text { Mean }\end{array}$ \\
\hline Total Purchase Price & 6.02 & 6.06 & 6.05 & 5.82 & 5.68 \\
\hline Utility Bill & 4.54 & 4.73 & 4.35 & 4.39 & 4.36 \\
\hline Long-Term Energy Cost & 4.47 & 4.63 & 4.34 & 4.30 & 4.20 \\
\hline Maintenance Cost & 4.46 & 4.68 & 4.30 & 3.95 & 4.16 \\
\hline Resale Value & 4.35 & 4.34 & 4.42 & 4.30 & 3.04 \\
\hline Down Payment & 4.15 & 4.22 & 3.92 & 4.87 & 3.96 \\
\hline Mortgage Length & 3.91 & 3.95 & 3.62 & 4.95 & 4.00 \\
\hline $\begin{array}{l}\text { Interest Rate on } \\
\text { Mortgage/Loan }\end{array}$ & 3.68 & 3.76 & 3.51 & 3.95 & 3.72 \\
\hline Lot/Park Rental Fee & 3.42 & 3.29 & 3.57 & 3.52 & 3.43 \\
\hline (a) 1 = "No Influence," 7 = "Strong Influence." & & & \\
\hline
\end{tabular}

by the long-term energy costs, the expected maintenance costs, the resale value, the down payment, the loan length, interest rate, and finally the lot/park rental fee.

The least influential economic factors at the regional level were the interest rate and the lot/park fee. The mean influence rating of the lot/park fee can be discounted at this point in the analysis as the home's location has not yet been accounted for. Later in Chapter 3 a more accurate ranking of the influence the lot fee has on the purchase decision is given by the manufactured home purchasers who did not site their home on their own private property. The finding regarding the interest rate should also be viewed with caution at this point in the analysis as the method of financing has not yet been controlled for. Discussions in later chapters explain that 
those who have to use a loan to purchase a home are likely to state that the loan's interest rate has a strong influence on their determination of a home's affordability.

Buyers clearly considered energy costs to be important considerations in the overall affordability of a manufactured home. Buyers in every state except ldaho ranked utility bills as the second most influential factor in affordability and long-term energy cost was the third most influential factor at the regional level. Although the results in Table 2.2 suggest that energy efficiency alone is not among the most important factors in the purchase decision, it appears that efficiency is still quite important through its effect on utility costs and, in turn, affordability.

\subsubsection{Home Feature Influences: Regional and State Results}

This section provides a brief discussion of the mean influence ratings associated with several features that may have influenced the home buyer's purchase decision. The respondents were again asked to think back to the purchase of their current manufactured home and rate the influence each of the following features had on their decision to purchase their home. The features included attractive floor coverings, a fireplace, painted and textured drywall, hardwood siding, energy-efficient windows, additional insulation, an efficient heating and cooling system, a shingle roof, attractive kitchen cabinets, a self-cleaning range, and the number of windows/window area. For the remainder of the report these features will be referred to as the home features. The mean responses to each of the home features are presented in Table 2.4.

It should be noted that, relative to the general purchase (Table 2.2) and economic affordability factors (Table 2.3), the influence generated by the home features (Table 2.4) is much weaker. Based on the mean influence scores, it appears that the general purchase factors tend to have the most influence, while the home features have much less influence.

On the regional level the most influential home feature was the number of windows/window area, followed by the existence of an efficient heating and cooling system. These two features are the most influential in each of the states. Specific energy-efficiency features were rated quite high relative to the other home features depicted in Table 2.4. Regionally, an efficient heating and cooling system, energyefficient windows, and additional insulation were among the top 5 of the 11 features considered. In Idaho and Montana, an efficient heating/cooling was the highest rated 
feature. It appears that much of the buyer emphasis on affordability is tied to utility bills which, in turn, are related to specific energy-efficiency features.

TABLE 2.4. Region and State Mean Home Feature Influence Ratings ${ }^{(\mathrm{a})}$

\begin{tabular}{|c|c|c|c|c|c|}
\hline Home Features & $\begin{array}{l}\text { Region- } \\
\text { Wide } \\
\text { Mean }\end{array}$ & $\begin{array}{l}\text { Washin } \\
\text { gton } \\
\text { Mean }\end{array}$ & $\begin{array}{l}\text { Oregon } \\
\text { Mean }\end{array}$ & $\begin{array}{l}\text { Idaho } \\
\text { Mean }\end{array}$ & $\begin{array}{c}\text { Montana } \\
\text { Mean }\end{array}$ \\
\hline $\begin{array}{l}\text { No. of Windows/Window } \\
\text { Area }\end{array}$ & 4.45 & 4.54 & 4.52 & 4.04 & 3.73 \\
\hline $\begin{array}{l}\text { Efficient Heating/Cooling } \\
\text { System }\end{array}$ & 4.34 & 4.42 & 4.37 & 4.04 & 3.82 \\
\hline $\begin{array}{l}\text { Attractive Kitchen } \\
\text { Cabinets }\end{array}$ & 4.04 & 4.19 & 4.04 & 3.54 & 3.30 \\
\hline Energy-Efficient Windows & 3.81 & 3.93 & 3.77 & 3.58 & 3.22 \\
\hline Additional Insulation & 3.79 & 3.98 & 3.66 & 3.45 & 3.47 \\
\hline Attractive Floor Covering & 3.72 & 4.01 & 3.46 & 3.52 & 3.00 \\
\hline Shingle Roof & 3.31 & 3.59 & 3.22 & 1.95 & 3.30 \\
\hline $\begin{array}{l}\text { Painted and Textured } \\
\text { Walls }\end{array}$ & 3.08 & 3.20 & 3.00 & 2.69 & 3.13 \\
\hline Hardwood Siding & 3.02 & 3.09 & 2.89 & 3.07 & 3.26 \\
\hline Self-Cleaning Range & 2.11 & 2.40 & 1.81 & 1.75 & 1.89 \\
\hline Fireplace & 1.97 & 1.97 & 1.93 & 2.42 & 1.56 \\
\hline
\end{tabular}

\subsection{NEW AND USED MANUFACTURED HOME PURCHASER PROFILES}

This section provides information on home buyers for the entire region reported for those who purchased a new home and those who purchased a used home. In the interest of presenting current data, only households who have purchased since 1985 were used in the analysis that generated the results presented in the following sections. About half the total survey respondents fell into this category. The following 
sections contain discussions regarding certain demographic variables, typical loan terms, and heating fuel usage and cost.

\subsubsection{Demographic and Manufactured Home Stock Comparisons}

Of the households that purchased their homes after $1984,36 \%$ purchased new homes and $64 \%$ purchased used homes. The average age of the household head for new-home purchasers was 54 , while the average age of used-home purchasers was 53. Table 2.5 contains the age distributions for the two groups.

TABLE 2.5. New and Used Home Buyer Household Head's Age Distribution

\begin{tabular}{|c|c|c|}
\hline Percentile & $\begin{array}{c}\text { New-Home Buyers' } \\
\text { Age Dist. }\end{array}$ & $\begin{array}{c}\text { Used-Home Buyers' } \\
\text { Age Dist. }\end{array}$ \\
\hline $100 \%$ & 87 & 91 \\
\hline $75 \%$ & 68 & 69 \\
\hline $50 \%$ (Median) & 54 & 52 \\
\hline $25 \%$ & 39 & 36 \\
\hline $0 \%$ & 25 & 22 \\
\hline
\end{tabular}

There was no significant difference in the average age of the two groups. The average household size for both the new and used purchasing households was just over two people. The median model year for new-home purchasers was 1988, while the median model year for used purchasers was 1976.

\subsubsection{Comparison of Financial Factors and Lending Practices}

For buyers who financed their home purchase, the median income at the time the manufactured home was purchased was $\$ 27,000$ for new-home buyers and $\$ 22,000$ for used-home buyers. ${ }^{(a)}$ Ten percent of the used-home buyers indicated their income was $\$ 10,000$ or less. Ten percent of the new-home buyers indicated their

(a) Those who paid cash for their homes were not asked about their median income at the time of purchase as the result of a skip pattern on the questionnaire. 
income was $\$ 15,000$ or less. New-home buyers had a median loan amount of $\$ 34,600$ and a quarter of them had loans for under $\$ 25,000$. Used-home buyers had a median loan amount of only $\$ 18,500$ and a quarter of them had loans for under $\$ 11,500$.

Seventy percent of the new-home buyers financed the purchase of their home through a new mortgage, and $30 \%$ paid cash. Thirty-eight percent of used-home buyers purchased their homes with a new mortgage; $43 \%$ paid cash, about $8 \%$ assumed an existing mortgage, and $11 \%$ used some other source of funds, such as a family loan, when they purchased their home. The most interesting finding from these data is the fact that nearly one-third of all new manufactured homes are paid for with cash. Thus, there clearly is a significant segment of the population that is unlikely to be affected by changes in lending practices.

The respondents were asked about the term of their loan, the down payment, the current interest rate, and the interest rate at the loan's origination date. The median loan term among new-home purchasers was 20 years; the median term among used-home purchasers was 13 years. At least $10 \%$ of both the new- and used-home buyers have a 30 -year loan. However, $25 \%$ of the used-home buyers reported having loan terms of 7 or fewer years. The median percentage down payment for both new- and used-home purchasers was $10 \%$. The current median interest rate on the mortgages is $11 \%$ for new-home purchasers and $10.5 \%$ for usedhome purchasers. One tenth of the new home buyers actually have rates at $8.5 \%$ or less $(5 \%$ had $8 \%$ or less). The median interest rate at origination was $12 \%$ for newhome buyers and $11 \%$ for used-home buyers.

Table 2.6 contains the terms associated with both the new- and used-home buyer's "typical" loan. The respondents were also asked about the size of their current principal and interest payments, their monthly lot/rent fees, their monthly property taxes, and their monthly home owner insurance payments. The median responses are shown on Table 2.6.

Eighty percent of the new-home buyers who took out loans have fixed-payment self-amortizing mortgages, while $16 \%$ have adjustable-rate mortgages; the rest had other types of loans. Eighty-four percent of the used-home buyers have fixed payment mortgages and $8 \%$ have adjustable rate mortgages; the rest had other types of loans. 
TABLE 2.6. Average Loan Features Comparison, New- and Used-Home Buyers

\begin{tabular}{||l|c|c||}
\hline \multicolumn{1}{|c|}{ Loan Term } & $\begin{array}{c}\text { New } \\
\text { Home } \\
\text { Buyer }\end{array}$ & $\begin{array}{c}\text { Used } \\
\text { Home } \\
\text { Buyer }\end{array}$ \\
\hline Household Income at Time of Purchase & $\$ 27,000$ & $\$ 22,000$ \\
\hline Mortgage Term at Time of Purchase & 20 & 13 \\
\hline Total Loan Amount at Time of Purchase & $\$ 34,600$ & $\$ 18,500$ \\
\hline $\begin{array}{l}\text { Percentage Down Payment at Time of } \\
\text { Purchase }\end{array}$ & $10 \%$ & $10 \%$ \\
\hline Current Interest Rate on the Mortgage & $11 \%$ & $10.5 \%$ \\
\hline Mortgage Interest Rate at Origination & $12 \%$ & $11 \%$ \\
\hline Monthly Principal and Interest Payment & $\$ 394$ & $\$ 269$ \\
\hline Monthly Park or Lot Rental Fee & $\$ 211$ & $\$ 175$ \\
\hline Monthly Property Tax Payment & $\$ 62$ & $\$ 32$ \\
\hline Monthly Home-Owner Insurance Payment & $\$ 22$ & $\$ 20$ \\
\hline
\end{tabular}

\subsubsection{Heating Fuel and Costs for New- and Used-Home Buyers}

The respondents were also asked about their primary heating fuel and about their annual heating bill. Sixty-eight percent of the new-home purchasers heat with electricity, $23 \%$ heat with wood, $7 \%$ heat with natural gas, and $2 \%$ use propane. Sixtyfive percent of the used-home buyers heat with electricity, $20 \%$ heat with wood, $12 \%$ heat with natural gas, and $3 \%$ use propane. The majority of both new- and usedhome buyers use a central forced-air furnace as the primary heating system.

The new-home buyers' average annual heating bill was $\$ 600$, and the median value was $\$ 508$. The used-home buyers' average annual heating bill was $\$ 648$, and the median value was $\$ 600$. Although many other characteristics affect energy consumption, these results suggest that the newer manufactured homes are more energy-efficient. The difference is best portrayed by the difference of nearly $\$ 100$ in the median heating bills (median values are less influenced by outlier values than simple averages). 


\subsubsection{Additional Comparisons of New- and Used-Home Buyers}

The respondents were told to think back to the purchase of their current home, then they were asked if they would have purchased $\$ 2,500$ worth of additional energyefficient features that would reduce their annual heating bills about $50 \%$. They were asked if they would have purchased the additional energy features under three different scenarios: if they were offered a $\$ 1,250$ cash rebate; if they were offered a 5year no-interest loan for the $\$ 2,500$, and if they were offered a relaxed loan qualification criteria that allowed them to qualify for a larger loan to cover the cost of the features. Seventy-one percent of the new-home buyers would have taken the rebate, while only $58 \%$ of the used-home buyers would have. Forty-seven percent of the newhome buyers would have taken the no-interest loan, while $51 \%$ of the used-home buyers would have taken it. Finally, only $34 \%$ of the new-home buyers and $38 \%$ of the used-home buyers would have purchased the ECMs if their lender had relaxed their loan qualification criteria.

These findings suggest that even if Bonneville is successful in getting lending institutions to modify their qualification criteria, a large percentage of the manufactured home buyers will not purchase energy-efficient features. Simply qualifying for a larger mortgage, as many energy-efficient mortgage programs permit, does not appear to be very appealing to a large portion of the market. Indeed, when the respondents who arranged their own financing were asked what loan feature had the most influence on their choice of mortgage, the qualification ratio was mentioned by only $3 \%$ of newhome buyers and $4 \%$ of used-home buyers. Forty percent of the new-home buyers said the mortgage interest rate had the most influence on their loan selection, followed by the monthly mortgage payment ${ }^{(\mathrm{al})}(26 \%)$, and the down payment $(10 \%)$. For the used-home buyer, $35 \%$ said the monthly payment had the most influence on their loan selection, while $30 \%$ said it was the interest rate, and $19 \%$ said it was the down payment.

Ninety-six percent of the new homes were purchased from dealers, and $4 \%$ from manufactured home parks. Sixty-four percent of used-home purchasers bought their home from a private party, $17 \%$ were purchased through a real estate agent, $12 \%$

(a) Although monthly payment can be determined from the interest rate, loan amount, down payment, and length of the loan, we included it for individual consideration in questions about the loan terms. This permits us to assess how important it is to the financing decision. For program design purposes, other loan features could be modified to affect the monthly payment. 
through dealers, $2 \%$ through brokers, and $2 \%$ through manufactured home parks. Twenty-four percent of the new-home buyers were first-time buyers, and $38 \%$ of the used buyers were first-time buyers. Twenty-one percent of the new-home buyers had rented their previous home while $79 \%$ had owned their previous home. Forty-nine percent of the used-home purchasers had rented their previous home while $51 \%$ had owned their previous home. Thus, it appears that many of the used homes are purchased by renters in search of equity.

Forty-five percent of the new-home purchasers moved from a site-built house, while $38 \%$ had lived in another manufactured home, and only $12 \%$ came from apartments. These data suggest that there have been some substitutions made (new for old) in the manufactured housing stock. Fifty-seven percent of the used-home purchasers lived in a site-built house prior to their current home, 19\% had lived in another manufactured home, and $16 \%$ had lived in an apartment.

Table 2.7 shows the percentage of new and used homes sited on the home buyers' land. These findings reveal the importance of improving the "home-only" loan packages offered to new-home purchasers. At least $47 \%$ of the purchasers of new homes do not purchase both the land and home together. These purchasers are not eligible for the home-land type mortgages that have become available in recent years; thus they are faced with the higher rates and shorter terms associated with the personal property loans that lenders typically use for homes not located on the owner's property (Sandahl et al. 1992).

TABLE 2.7. Manufactured Home Siting Distribution

\begin{tabular}{|l|c|c|}
\hline \multicolumn{1}{|c|}{ Location } & New-Home Buyer & Used-Home Buyer \\
\hline Private Property & $49 \%$ & $36 \%$ \\
\hline Manufactured Home Park & $40 \%$ & $53 \%$ \\
\hline Someone Else's Property & $7 \%$ & $8 \%$ \\
\hline Subdivision & $4 \%$ & $3 \%$ \\
\hline
\end{tabular}




\subsubsection{The Influence of General Purchase Factors: New- and Used-Home Buyers}

With regard to the general factors that can influence a purchase decision, the new-home buyers said the most influential factor was the home's floor plan. It was followed by the home's affordability, the size of the home, the construction quality, its energy efficiency, aesthetic appeal, and finally the home's location. The used-home buyers said that the home's affordability was the most influential factor. It was followed by the size of the home, its location, floor plan, the quality of its construction, aesthetic appeal, and finally energy efficiency. The new-home buyers placed significantly more influence on the home's floor plan, size, construction quality, energy efficiency, and aesthetic appeal than did the used-home buyers. ${ }^{(b)}$

As expected because used homes are usually already located at a specific site, used-home buyers considered the home's location significantly more influential than did the new-home buyers $\left(5.18\right.$ versus $\left.3.71, P=.05^{(b)}\right)$. There was no significant difference in the influence ratings associated with a home's affordability. All the other mean ratings, however, were significantly different from each other. The mean influence scores for each of the factors are presented in Table 2.8. Bonneville should take note of these results, particularly the relative ranking of energy efficiency for those who purchased used homes since 1985.

This table shows that the small influence of energy efficiency exhibited in Table 2.2 results from the fact that used-home buyers comprise a majority (approximately two-thirds) of the sample of buyers. New-home buyers consider energy efficiency to be much more influential in their purchase decision, ranking it fifth of eight factors examined, rather than last as buyers of used homes do. Because energy efficiency appears to have a comparatively small influence on the purchase decision of usedhome buyers, a regional energy-efficiency retrofit program may be difficult to sell, and should be designed to reflect the relatively low influence that it seems to have on people who purchase used manufactured homes.

(a) The differences in the two groups' mean influence scores were found to be statistically significant at the $95 \%$ confidence level using t-tests.

(b) Throughout this report, values of $\mathrm{P}$ are shown to indicate the probability that a difference as large as that found in this sample would occur in a random sample of the population: the lower the $P$ value, the less likely that the populations being compared have the same value for the characteristic being considered. 
TABLE 2.8. New- and Used-Home Buyers' Mean General Purchase Factor Influence Ratings ${ }^{(\mathrm{s})}$

\begin{tabular}{||l|c|c||}
\hline \multicolumn{1}{|c|}{ General Purchase Factor } & $\begin{array}{c}\text { New } \\
\text { Home } \\
\text { Buyer }\end{array}$ & $\begin{array}{c}\text { Used } \\
\text { Home } \\
\text { Buyer }\end{array}$ \\
\hline Floor Plan & 6.46 & 4.91 \\
\hline Affordability & 6.21 & 6.38 \\
\hline Home Size & 6.13 & 5.22 \\
\hline Construction Quality & 6.08 & 4.33 \\
\hline Energy Efficiency & 5.74 & 3.95 \\
\hline Aesthetic Appeal & 5.52 & 4.11 \\
\hline Amenities & 4.75 & 4.08 \\
\hline Location & 3.71 & 5.18 \\
\hline (a) $1=$ "No Influence," 7 = "Strong Influence." & & \\
\hline
\end{tabular}

\subsubsection{Factors Determining Affordability: New- and Used-Home Buyers}

This section compares the new- and used-home buyer responses regarding the economic affordability factors. The new-home buyers' and used-home buyers' mean influence ratings for each of these factors are presented in Table 2.9.

For the used-home buyers, the home's total purchase price had the most influence. The influence of the total purchase price was followed by the influences associated with the down payment, the monthly utility bills, the likely resale value of the home, the expected maintenance costs, the long-term heating and cooling costs, the length of the mortgage, the lot/park fee, and finally the interest rate on the mortgage.

For the new-home buyers, the home's total purchase price also had the most influence. Following the total purchase price, however, new-home buyers' and usedhome buyers' scores differed substantially. For the former group, the influence of the total purchase price was followed by the long-term heating and cooling costs, the monthly utility bills, the expected maintenance costs, the likely resale value, the down payment, the length of the mortgage, the interest rate of the mortgage, and finally the lot/park fee. 
TABLE 2.9. New- and Used-Home Buyers' Mean Affordability Factor Influence Ratings ${ }^{(a)}$

\begin{tabular}{||l|c|c||}
\hline \multicolumn{1}{|c|}{ Economic Affordability Factors } & $\begin{array}{c}\text { New } \\
\text { Home } \\
\text { Buyer }\end{array}$ & $\begin{array}{c}\text { Used } \\
\text { Home } \\
\text { Buyer }\end{array}$ \\
\hline Total Purchase Price & 5.87 & 6.11 \\
\hline Long-term Heating and Cooling Cost & 5.08 & 4.12 \\
\hline Monthly Utility Bill & 5.07 & 4.22 \\
\hline Expected Maintenance Cost & 5.02 & 4.13 \\
\hline Likely Resale Value & 4.71 & 4.14 \\
\hline Down Payment & 4.03 & 4.23 \\
\hline Interest Rate on Mortgage/Loan & 3.97 & 3.51 \\
\hline Length of the Mortgage/Loan & 3.97 & 3.88 \\
\hline Lot/Park Rental Fee & 2.89 & 3.74 \\
\hline (a) 1 = "No Influence," 7 = "Strong Influence." & & \\
\hline
\end{tabular}

The responses of the new-home buyers indicate that they tend to assess almost all of the economic affordability factors (except total purchase price) as more influential than the used-home buyers do. These results suggest that new-home buyers have a broader view of what affordability means, attributing more influence to several economic components. New-home buyers seem to be relatively sophisticated in terms of understanding the role maintenance and operating costs play in ultimately determining how affordable a home is. For used-home buyers, the results suggest that affordability is largely driven by the home's purchase price. The down payment and monthly utility billed are essentially tied as the second most important determinants of affordability for used-home buyers.

Consistent with the results for energy efficiency as a factor affecting the purchase decision, new-home buyers consider both long-term heating costs and the monthly utility bill as very important determinants of affordability. Used-home buyers score these two economic factors as significantly less influential. 


\subsubsection{Home Feature Influences: New- and Used-Home Buyers}

This section compares the new-home buyers' and used-home buyers' mean influence ratings associated with home features. The mean responses are presented in Table 2.10.

The differences between all the new- and used-home buyer's mean ratings were statistically significant at the 0.05 significance level. New-home buyers' mean influence ratings were significantly higher than the influence ratings of the used-home buyers for all of the home features except for the fireplace.

TABLE 2.10. New- and Used-Home Buyers' Mean Home Feature Influence Ratings ${ }^{(a)}$

\begin{tabular}{||l|c|c||}
\hline \multicolumn{1}{|c|}{ Home Features } & $\begin{array}{c}\text { New } \\
\text { Home } \\
\text { Buyer }\end{array}$ & $\begin{array}{c}\text { Used } \\
\text { Home } \\
\text { Buyer }\end{array}$ \\
\hline No. of Windows/Window Area & 5.41 & 3.86 \\
\hline Efficient Heating/Cooling System & 5.39 & 3.72 \\
\hline Attractive Kitchen Cabinets & 5.38 & 3.24 \\
\hline Additional Insulation & 5.30 & 2.88 \\
\hline Energy-Efficient Windows & 5.05 & 3.07 \\
\hline Shingle Roof & 4.94 & 2.28 \\
\hline Attractive Floor Covering & 4.80 & 3.08 \\
\hline Painted and Textured Walls & 4.74 & 2.04 \\
\hline Hardwood Siding & 4.30 & 2.22 \\
\hline Self-Cleaning Range & 2.59 & 1.81 \\
\hline Fireplace & 1.70 & 2.13 \\
\hline (a) 1 = "No Influence," 7 = "Strong Influence." & & \\
\hline
\end{tabular}


In the context of the other influence factor results for used-home buyers, the ratings for all the home features are consistently low. One interpretation of these results is that used-home buyers are quite sensitive to affordability factors, especially purchase price, and are willing to trade off home features for a lower purchase price.

For the new-home buyers, the feature related to window area was the most influential. It was followed by the efficient heating and cooling system, attractive kitchen cabinets, additional insulation, energy-efficient windows, a shingle roof, attractive floor coverings, painted and textured drywall, hardwood siding, a selfcleaning range, and finally a fireplace.

The high influence ratings that new-home buyers give to efficient windows, added insulation, and efficient heating and cooling systems is a marked difference from the low influence ratings that used-home buyers give these features. This result is consistent with the higher influence new-home buyers attribute to energy efficiency in their purchase decision and the higher influence they give utility bills and energy costs in their assessment of affordability. Although much of the difference between the influence on new- and used-home buyers may be attributable to fundamental differences in attitudes and preferences, some of this difference may well be the result of Bonneville's activity in the Northwest's manufactured housing industry and market. 


\subsection{STATISTICS FOR HOME-LAND PURCHASES AND HOME-ONLY PURCHASES}

This chapter compares manufactured home owners who sited their homes on their own private property with thcse who sited their homes on someone else's property. This is generally thought to be an important distinction because home-land purchases are more like site-built home purchases and lenders may provide loans for them at more favorable loan terms (e.g., longer loan term, lower interest rate, etc.) than they do for home-only purchases. ${ }^{(a)}$ For our purposes, home-land purchases are defined as homes that are permanently attached to a foundation on the owner's own property; the land was not necessarily purchased with the home.

For convenience, abbreviations will be used in the rest of this chapter to refer to home-land and home-only purchasers. Home-land purchasers will be referred to as "HLs" and home-only purchasers will be referred to as "HOs". The analysis results presented in this chapter are based on the responses of manufactured home owners who purchased new and used manufactured homes after the end of 1984 . Of all the manufactured homes purchased after $1984,42 \%$ are HLs and $58 \%$ are HOs.

\subsection{DEMOGRAPHIC PROFILES OF HOME-LAND AND HOME-ONLY PURCHASERS}

HLs tended to be younger; the average age for the household head in this group was 50 , while the average age for the HOs was 56. Table 3.1 contains the age distribution for the heads of households for the HOs and HLS.

These data suggest that there are more older retired people buying manufactured homes destined for a manufactured home park. This may be because of the convenience of living in a manufactured home park (e.g., less yard care).

The mean household size in the HL group is significantly larger than the mean household size in the $\mathrm{HO}$ group (2.63 versus $2.07, \mathrm{p}=.05$ ). Single-person households make up a large percentage of the HOs. Table 3.2 contains the distribution of household size for the HLs and HOs.

(a) There is evidence that some lending institutions do treat manufactured homes permanently located on their owner's own property the same way they treat site-built homes (Sandahl et al. 1992). 
TABLE 3.1. Home-Lands and Home-Onlys Head of Household Age Distribution

\begin{tabular}{|c|c|c|}
\hline Percentile & $\begin{array}{c}\text { Home-Lands Age of Head } \\
\text { of Household }\end{array}$ & $\begin{array}{c}\text { Home-Onlys Age of Head } \\
\text { of Household }\end{array}$ \\
\hline $100 \%$ & 82 & 91 \\
\hline $75 \%$ & 62 & 71 \\
\hline $50 \%$ (Median) & 48 & 60 \\
\hline $25 \%$ & 36 & 41 \\
\hline $0 \%$ & 24 & 22 \\
\hline
\end{tabular}

TABLE 3.2. Household Size Distributions for Home-Lands and Home-Onlys

\begin{tabular}{|c|c|c|}
\hline Number of People & Home-Lands & Home-Onlys \\
\hline 1 & $14 \%$ & $35 \%$ \\
\hline 2 & $44 \%$ & $41 \%$ \\
\hline 3 & $17 \%$ & $10 \%$ \\
\hline 4 & $18 \%$ & $10 \%$ \\
\hline $5+$ & $8 \%$ & $4 \%$ \\
\hline
\end{tabular}

The employment status distributions for both the male and female heads of households for both the HOs and HLs are presented in Table 3.3. The HOs have a much higher percentage of retirees.

The two groups also differ with regard to the types of family found in each group. Table 3.4 contains the distribution of HOs and HLs by family type. Husbandwife families are the dominant family type in both, but comprise a considerably larger percentage in the HLS than the HOs. On the other hand, the HOs have a large percentage of lone females. The data suggest that single, retired women may make up a large part of the $\mathrm{HO}$ group. 
TABLE 3.3. Household Heads Employment Status for Home-Lands and Horne-Onlys

\begin{tabular}{||l|c|c|c|c||}
\hline \multirow{2}{*}{ Employment Status } & \multicolumn{2}{|c|}{ Male Household Head } & \multicolumn{2}{|c|}{$\begin{array}{c}\text { Female Household } \\
\text { Head }\end{array}$} \\
\cline { 2 - 5 } & $\begin{array}{c}\text { Home- } \\
\text { Lands }\end{array}$ & $\begin{array}{c}\text { Home- } \\
\text { Onlys }\end{array}$ & $\begin{array}{c}\text { Home- } \\
\text { Lands }\end{array}$ & $\begin{array}{c}\text { Home- } \\
\text { Onlys }\end{array}$ \\
\hline Work Full Time & $68 \%$ & $43 \%$ & $38 \%$ & $29 \%$ \\
\hline Work Part Time & $3 \%$ & $7 \%$ & $21 \%$ & $17 \%$ \\
\hline Retired & $23 \%$ & $43 \%$ & $18 \%$ & $35 \%$ \\
\hline Not Employed & $3 \%$ & $4 \%$ & $20 \%$ & $14 \%$ \\
\hline
\end{tabular}

TABLE 3.4. Types of Families in the Home-Onlys and Home-Lands

\begin{tabular}{||l|c|c|}
\hline \multicolumn{1}{|c|}{ Family Type } & Percentage of HLs & Percentage of HOs \\
\hline $\begin{array}{l}\text { Husband and Wife } \\
\text { Families }\end{array}$ & $75 \%$ & $57 \%$ \\
\hline Single Fathers & $2 \%$ & $0 \%$ \\
\hline Single Mothers & $6 \%$ & $6 \%$ \\
\hline Lone Males & $5 \%$ & $6 \%$ \\
\hline Lone Females & $9 \%$ & $28 \%$ \\
\hline $\begin{array}{l}\text { Male or Female Living } \\
\text { with a Relative }\end{array}$ & $3 \%$ & $2 \%$ \\
\hline
\end{tabular}

The average median household income at the time of purchase was higher for the HLs than it was for the HOs $(\$ 28,000$ versus $\$ 22,000)$. Median values were reported because of the existence of outlier values that tended to exaggerate the difference. The two groups' current household income distributions are presented in Table 3.5. The current household income data were collected in ranges so it was impossible to calculate a median value for the current household income. Based on the income distribution data, HLS appear to have higher incomes than HOs. 
TABLE 3.5. Home-Land and Home-Only Household Income Distribution

\begin{tabular}{|c|c|c|}
\hline Income Category & Percentage of HLs & Percentage of HOs \\
\hline Less than $\$ 12,500$ & $10 \%$ & $21 \%$ \\
\hline$\$ 12,500-\$ 24,999$ & $26 \%$ & $36 \%$ \\
\hline$\$ 25,000-\$ 39,999$ & $33 \%$ & $32 \%$ \\
\hline$\$ 40,000-\$ 59,999$ & $24 \%$ & $9 \%$ \\
\hline$\$ 60,000+$ & $8 \%$ & $2 \%$ \\
\hline
\end{tabular}

\subsubsection{Implications from the Demographic Proflles}

These data may have implications for regional manufactured housing programs. Because home/land purchases are more like site-built home purchases, we would expect HLs to get better loan terms. The data presented in Table 3.6, however, do not completely support that notion.

TABLE 3.6. Loan Term Comparison of Home-Lands and Home-Onlys

\begin{tabular}{||l|c|c||}
\hline \multicolumn{1}{|c|}{ Loan Term } & $\begin{array}{c}\text { Home Land } \\
\text { Buyer }\end{array}$ & $\begin{array}{c}\text { Home Only } \\
\text { Buyer }\end{array}$ \\
\hline Household Income at Time of Purchase & $\$ 28,000$ & $\$ 22,000$ \\
\hline Mortgage Term at Time of Purchase & 15 & 15 \\
\hline Total Loar. Amount at Time of Purchase & $\$ 35,000$ & $\$ 19,261$ \\
\hline $\begin{array}{l}\text { Percentage Down Payment at Time of } \\
\text { Purchase }\end{array}$ & $16 \%$ & $10 \%$ \\
\hline Current Interest Rate on the Mortgage & $10 \%$ & $12 \%$ \\
\hline Mortgage Interest Rate at Origination & $10 \%$ & $12 \%$ \\
\hline Monthly Principal and interest Payment & $\$ 384$ & $\$ 263$ \\
\hline Monthly Park or Lot Rental Fee & -- & $\$ 185$ \\
\hline Monthly Property Tax Payment & $\$ 60$ & $\$ 35$ \\
\hline Monthly Home Owner Insurance Payment & $\$ 25$ & $\$ 18$ \\
\hline
\end{tabular}


As the reader can see, the median loan terms for HLs and HOs are identical, and the median down payment is actually smaller for the HOs. Lenders do appear to be providing the HLS a lower interest rate relative to the HOs.

The respondents who financed their home through a new mortgage were asked to identify the loan feature that had the most influence on their choice of mortgage. Forty percent of the HLs indicated the interest rate had the most influence, $24 \%$ indicated it was the monthly payment, $14 \%$ said it was the down payment requirement, $5 \%$ said it was the length of the loan, $4 \%$ said it was the debt-to-income qualification ratio, and $3 \%$ said it was the loan fee. A similar pattern was revealed by the HOs except the first two features switched places. Thirty-seven percent of the HOs said the monthly payment had the most influence on their choice of mortgage, $25 \%$ indicated it was the interest rate, $16 \%$ said it was the down payment requirement, $5 \%$ indicated the loan lerigth, $4 \%$ said it was the debt-to-income qualification ratio, and $2 \%$ said it was the loan fee.

\subsubsection{Additional Comparisons Between Home-Land and Home-Only Purchasers}

As stated earlier, the responses of those who purchased their current manufactured home after 1984 were used to support the analysis presented here. Thirty-two percent of the households that purchased a manufactured home since the end of 1984 were first-time buyers. Forty percent of the first-time buyers were HLS and $60 \%$ of the first-time buyers were HOs.

Based on how long the survey respondents indicated they planned to stay in their current home, we estimated that half of all the HLs would stay in their current manufactured home 16 years or less from the date of the survey, while half of the HOs would stay for seven years or less. ${ }^{(a)}$

Half of the HLs purchased their homes after $1988 ; 50 \%$ of these homes were built after 1984. Half the HOs purchased their homes after $1989 ; 50 \%$ of these homes were built before 1979. Thus it appears that the manufactured housing stock owned by the HOs tends to be older.

(a) Tenure was calculated for those who said they planned to stay in their current home "forever" by subtracting their age from standard life expectancy figures for males and females. 
Fifty percent of the HLs purchased their home from a dealer, while only $37 \%$ of the HOs bought theirs from a dealer. Many of the HOs (47\%) purchased their home from a private party. It should be noted though that dealer sales appear to be split evenly between HLs and HOs. Forty-four percent of the HLs purchased new homes, while $56 \%$ purchased used homes. Thirty percent of the HOs purchased new homes while $70 \%$ purchased used homes.

\subsection{FACTORS AFFECTING HOME-LAND AND HOME-ONLY PURCHASERS}

The following sections discuss the similarities and differences observed in how different factor's affect home-land and home-only purchasers. The discussion addresses general purchase factors, economic affordability factors, and home features.

\subsubsection{The Influence of General Purchase Factors}

This section compares the HLs' and HOs' responses related to the general purchase factors (i.e., floor plan, affordability, home size, etc.). Both groups indicated affordability had the most influence on their purchase decision. The next most influential factors were the size of the home and the home's floor plan. HLs and HOs rated the influence of all factors similarly, except location and the home's amenities. Fnergy efficiency, by itself, was rated the fíth most influential factor by HLs and the seventh by HOs (out of eight factors).

HLs were less influenced by location than HOs (4.18 versus $5.14, P=.05)$. This result makes sense because those who buy a home that is sited on their own property do not have to take the location into account as much in the home purchase decision. HLs were less influenced by the home's amenities than the HOs (4.11 versus 4.57 , $P=.05$ ). This is consistent with the fact that HOs tended to be older households, and older households were more influenced by a home's amenities than younger households. The mean influence ratings for each of the general factors are presented in Table 3.7. ${ }^{\text {(a) }}$

(a) The results in this and subsequent tables are presented in order of influence as indicated by home/land purchasers. 
TABLE 3.7. Home-Land and Home-Only Mean General Purchase Factor Influence Ratings ${ }^{(\mathbf{a})}$

\begin{tabular}{||l|c|c|}
\hline \multicolumn{1}{|c|}{ General Purchase Factor } & Home Land Buyer & Home Only Buyer \\
\hline Affordability & 6.33 & 6.27 \\
\hline Home Size & 5.55 & 5.55 \\
\hline Floor Plan & 5.44 & 5.51 \\
\hline Construction Quality & 5.06 & 4.96 \\
\hline Energy Efficiency & 4.70 & 4.58 \\
\hline Aesthetic Appeal & 4.65 & 4.70 \\
\hline Location & 4.18 & 5.14 \\
\hline Amenities & 4.11 & 4.57 \\
\hline (a) $1=$ "No Influence," $7=$ "Strong Influence." \\
\hline
\end{tabular}

\subsubsection{Factors Determining Affordability}

Both the HOs and HLs indicated that the home's total purchase price had the most influence in their affordability determinations. As noted earlier, the strong role played by the purchase price in the buyers' view of affordability is consistent with similar findings reported in Sandahl et al. (1992) and Onisko (1989).

For the HLs, the expected maintenance costs and the monthly utility bills were the next two most influential factors. For the HOs, the monthly lot/park fee and the utility bill were the most influential factors.

The difference in influence ratings for the two groups was statistically significant for four of the nine factors. These four factors were the mortgage rate, the down payment, the mortgage length, and the lot/park fee.

HLS indicated a significantly stronger influence of the mortgage rate (4.16 versus 3.32, $\mathrm{P}=.05$ ) than the HOs. The HLs also showed a significantly stronger influence of the down payment than the HOs did (4.50 versus $3.78, P=.05)$. The length of the mortgage also had significantly more influence on the HLs' determination of 
affordability than it did on the HOs (4.29 versus $3.52, P=.05)$. The only economic factor that had significantly more influence on the HOs' determination of affordability than it did on the HLs' was the lot/park rent (1.54 versus $4.78, P=.05){ }^{\left({ }^{(a)}\right.}$ Table 3.8 contains the mean influence ratings for all the economic affordability factors.

In general the HLs indicated that the two terms associated with a mortgage had more influence on their affordability determination than the HOs did. However, it should be noted that between $20 \%$ and $25 \%$ indicated these mortgage-related factors had no influence. The data suggest that these HLs may have purchased used homes with cash or some other means of financing. Future research should explore this subpopulation more thoroughly.

TABLE 3.8. Home-Land and Home-Only Mean Economic Affordability Factor Influence Ratings ${ }^{(a)}$

\begin{tabular}{||l|c|c||}
\hline \multicolumn{1}{|c|}{ Economic Affordability Factor } & Home Land Buyer & Home Only Buyer \\
\hline Total Purchase Price & 6.00 & 6.03 \\
\hline Expected Maintenance Cost & 4.59 & 4.49 \\
\hline Monthly Utility Bill & 4.52 & 4.62 \\
\hline Long-Term Heating and Cooling Cost & 4.50 & 4.53 \\
\hline Down Payment & 4.50 & 3.78 \\
\hline Length of the Mortgage/Loan & 4.29 & 3.52 \\
\hline Likely Resale Value & 4.23 & 4.53 \\
\hline Interest Rate on Mortgage/Loan & 4.16 & 3.32 \\
\hline Lot/Park Rental Fee & 1.54 & 4.78 \\
\hline (a) 1 = "No Influence," 7 = "Strong Influence." & \\
\hline
\end{tabular}

(a) It is not clear why the mean score for the HLs does not equal 1.0, as would be expected. One possible explanation is that a small fraction of the HLs misunderstood the question or are making separate payments to purchase their lot. 
The responses do indicate that energy costs and utility bills are a consideration in the home buyer's determination of affordability. This is especially true for the HOs who gave these factors their third and fourth (of nine) highest average scores. These two factors also made the HLs' top five. Although the results in Table 3.7 show that energy efficiency by itself is not considered highly important in the purchase decision, utility bills are considered important factors in determining affordability, which is the main factor in the purchase decision.

\subsubsection{Home Feature Influences}

Comparisons of the HLs' and HOs' mean influence ratings associated with the home features are presented in Table 3.9. Both the HLS and HOs indicated that the number of windows/window area was the most influential of the home features. The next most influential feature was an efficient heating/cooling system. The ratings for the top nine (of the eleven) features were in a fairly small range. The only significant differences in influence ratings, both when compared with other features and when compared across the two buyer groups, are associated with the fireplace and the shingle roof.

Information about the primary heating fuel helps explain the significant difference associated with the influence a fireplace has on the HLs' and HOs' purchase decisions. While $33 \%$ of the HLs rely heavily on wood for heating, only $8 \%$ of the HOs do. This explains both the low mean influence ratings associated with fireplaces (i.e., most manufactured home owners don't use them for heat) and the statistically significant difference observed between HLS and HOs.

The significant difference in influence ratings for the shingle roof may reflect the fact that HLs tended to have newer homes than HOs did. Shingles are offered more frequently on new homes than they have been in the past, thus they have more influence when they are available. Even though the difference in influence is statistically significant, it is not clear whether the difference is meaningful.

The home features related to energy efficiency - efficient heating and cooling system, additional insulation, and energy-efficient windows - all received relatively high ratings. Both $\mathrm{HLS}$ and $\mathrm{HOs}$ rated these features as among the most influential. 
TABLE 3.9. Comparison of Mean Home Feature Influence Ratings ${ }^{(a)}$

\begin{tabular}{||l|c|c|}
\hline \multicolumn{1}{|c|}{ Home Features } & Home Land Buyer & Home Only Buyer \\
\hline No. of Windows/Window Area & 4.45 & 4.53 \\
\hline Efficient Heating/Cooling System & 4.38 & 4.38 \\
\hline Attractive Kitchen Cabinets & 4.09 & 4.04 \\
\hline Additional Insulation & 3.95 & 3.70 \\
\hline Attractive Floor Covering & 3.83 & 3.65 \\
\hline Shingle Roof & 3.76 & 2.92 \\
\hline Energy-Efficient Windows & 3.75 & 3.90 \\
\hline Painted and Textured Walls & 3.27 & 2.96 \\
\hline Hardwood Siding & 3.08 & 2.98 \\
\hline Fireplace & 2.20 & 1.78 \\
\hline Self-Cleaning Range & 2.07 & 2.13 \\
\hline (a) 1 = "No Influence," 7 = "Strong Influence." & \\
\hline
\end{tabular}

\subsubsection{The Role of Energy Etficiency}

Although energy efficiency was about half way down the list of influential factors in the home owner's purchase decision, utility bills and long-term heating and cooling costs were among the most significant factors in the home owner's determination of affordability, especially for HOs. Affordability, in turn, was the primary factor in the purchase decision. Buyers also rated the influence of specific energy-efficiency features as among the most important in their home selection process. It appears, therefore, that both types of buyers discussed here believe that specific energy-efficiency features can produce benefits that translate into increased affordability, the number one concern of manufactured home buyers. 


\subsection{SEGMENTATION APPROACHES}

This chapter discusses two different market segmentation approaches, one involving life-cycle segments, and one based on the use of Areas of Dominant Influence (ADI). The first segmentation scheme uses demographic information to categorize households into similar groups. The second uses ADIs, which are geographic divisions defining television markets based on measurable viewing patterns. The early sections of this chapter discuss the results of the life-cycle segmentation and the later sections discuss an example of the ADI-based segments and how Bonneville might use them in targeting advertising for future manufactured home programs.

\subsection{LIFE-CYCLE SEGMENTATION}

Life-cycle segments are typically developed using several demographic variables to classify each household into a similar group. The life-cycle segments developed for this study used information regarding employment status, marital status, age of household heads, and the presence or absence of children. The process followed to develop the life-cycle segments is described in Appendix A. The 12 segments shown in Table 4.1 were created.

\subsubsection{Life-Cycle Segment Proportions}

Each of the 12 segments will be discussed in the remainder of this section. As in the previous sections, only the responses of those who purchased their manufactured home after 1984 are discussed. It should be noted that the relative proportion of younger households increased as a result of selecting only those who purchased their current manufactured home after 1984. Young families represent the largest single segment, with about $23 \%$ of the sample. The next largest segment is retired couples $(20 \%)$, followed by empty nesters with $13 \%$ of the population. In general terms about one-third of the manufactured home owning population is under 40 years of age, one-third is between 40 and 65 , and one-third is 65 or older. The relative proportions for each segment are given in Table 4.1. 
TABLE 4.1. Relative Proportions of Life-Cycle Segments

\begin{tabular}{|l|c|c|}
\hline Segment Name & Number & Relative Proportion \\
\hline Newlyweds & 23 & $4.3 \%$ \\
\hline Early Families & 121 & $22.8 \%$ \\
\hline Single Heads & 24 & $4.5 \%$ \\
\hline Late Families & 23 & $4.3 \%$ \\
\hline Young Males & 16 & $3.0 \%$ \\
\hline Young Females & 11 & $2.0 \%$ \\
\hline Empty Nesters & 69 & $13.0 \%$ \\
\hline Mid-Age Males & 13 & $2.5 \%$ \\
\hline Mid-Age Females & 53 & $10.0 \%$ \\
\hline Retired Couples & 107 & $20.2 \%$ \\
\hline Widows & 58 & $10.9 \%$ \\
\hline Widowers & 12 & $2.3 \%$ \\
\hline
\end{tabular}

\subsubsection{Life-Cycle Segment Profiles}

This section provides a short profile of the households in each of the life-cycle segments. ${ }^{(\mathbf{a})}$

Newlyweds: The average age of the head of the household in this segment is 35. The average household has two adults and no children. These couples plan to remain in their manufactured home an average of 12 years. ${ }^{(b)}$ Households in this segment who purchased from a manufactured home dealer visited an average of 4.1

(a) The reader should note that some of the average figures presented in the segment profiles may be subject to wide variance. This is especially true in the segments with fewer than 20 households from which to draw an average.

(b) All the figures reported here for how long occupants plan to stay in their home indicate how much longer they plan to stay. For a discussion of the total length of stay, or tenure, see Kavanaugh et al. (1993). 
dealers. Those who arranged their own financing visited 2.8 lenders, near the top of all the segments. Their total loan at the time of purchase averaged $\$ 37,188$. Their income at the time of purchase averaged $\$ 26,808$.

Early Families: These households are young families, with an average age of 35 for the head of the household. These households have an average of four people: 2 adults and 2 children. These households plan to remain in their current manufactured home an average of 18 years. Those who purchased from a dealer shopped at an average of 4.6 dealers and those who arranged their own financing shopped at 2.3 lenders on average. At the time of purchase their total loan averaged $\$ 31,429$, while their average income was $\$ 27,213$.

Single Heads: Households in this segment are single-parent families. The household head tends to be slightly older than their counterparts in the Newlywed and Early Families segments. The average age of the head of the household is 39. Their household size is an average of 2.87 people with one working adult and at least one child under 21 living at home. They plan to remain in their current home an average of 16 years. Those who purchased from a dealer shopped at an average of 4.75 dealers, while those who arranged their own financing shopped at 1.5 lenders. At the time of purchase their average loan was only $\$ 19,581$ and their average income was $\$ 16,882$.

Late Families: The households in this segment are families with an older husband and wife with an average age of 49 . These households average 3.73 people with 1.69 children under 21 still living at home. They plan to remain in their current home an average of 19 years. Those who purchased from a dealer went to 5.07 dealers on average when they were shopping for a home. Those who arranged their own financing shopped at 2.14 lenders on average. At the time of purchase their average loan amount was $\$ 39,950$ and their average income was $\$ 30,846$. This segment took the largest average loan when purchasing a manufactured home and had the second highest average income at the time of purchase.

Young Males: Households in this segment are headed by single males under 40 years of age, their average age is 32 , and there are no children living at home. The average household size is 1.31 people. They plan to stay in their current home for 11 years. Those who purchased from a dealer shopped at 4 dealers, and those who arranged their own financing visited 3.0 lenders. At the time of their purchase, their average loan was $\$ 25,656$ and their average income was $\$ 22,750$. 
Young Females: The households in this segment are headed by single females with an average age of 32 . There are no children in these households and the average household has 1.18 people. They plan to stay in their home an average of 14 years. Those who purchased from a dealer shopped at 3 dealers on average and those who arranged their own financing visited 2.7 lenders. Their average loan at the time of purchase was for $\$ 22,750$ while their average income was $\$ 22,800$.

Empty Nesters: The households in this segment are older couples who are still working. The average age of the head of the household is $\mathbf{5 9}$ and there are no children under 21 living at home. The average household in this segment has 2.2 people and they plan on living in their homes for 16 years. Those who purchased from a dealer shopped at 6.6 dealers and those who arranged their own financing visited an average of 1.7 lenders. This segment's average loan amount at the time of purchase is $\$ 31,755$ and their average income is $\$ 44,874$. This segment had the largest average income at the time they purchased their current manufactured home and appears to have the most active shoppers based on the highest average number of dealer visits across the segments.

Mid-Age Males: These households have single male heads over 40 , their average age is 48 , and there are no children living in their homes. The average household has 1.53 people. Households in this segment plan on remaining in their current home for 17 years. Those who purchased through dealers shopped at 3.1 dealers and those who arranged their own financing visited an average of 2 lenders. At the time of purchase this segment's average loan amount was $\$ 31,142$ and its average income was $\$ 30,071$.

Mid-Age Females: These households have single female heads over 40 , their average age is 54 , and there are no children in their homes. The average household has 1.3 people. Households in this segment plan on remaining in their current home for 22 years on average. Those who purchased through dealers shopped at 5.7 dealers and those who arranged their own financing visited an average of 1.6 lenders. At the time of purchase this segment's average loan amount was $\$ 26,414$ and its average income was $\$ 29,333$.

Retired Couples: The households in this segment are made up of retired couples, and they account for about $20 \%$ of the manufactured home-owning population. Their head of household's average age is 71 ; the households have two adults and no children. This segment only plans on living in their current home for 10 more years. For those who purchased from a dealer they shopped at an average of 4.5 dealers. For those who arranged their own financing they shopped at an average 
of 1.10 lenders. At the time they purchased their manufactured home their average loan was for $\$ 26,942$. At that same time their average household income was $\$ 24,635$.

Widows: These households are made up of single, retired women; their average age is 71 , and their average household size is 1.0 . They plan on living in their current home for an average of 10 years. For those who purchased their home through a manufactured home dealer they shopped at an average of 3.5 dealers. For those who arranged their own financing the average number of lenders visited was 2.14. At the time of their home purchase their average home loan was for $\$ 22,000$ and their average income was only $\$ 13,571$.

Widowers: Households in this segment are retired, single men. Their average age is 68; the average household size is 1.1 people and there are no children. They plan on living in their homes for an average of only 6.8 years. For those who purchased at a dealer the average number of dealers visited was 3.0. Those who arranged their own financing only visited one lender on average. At the time of purchase this segment's average loan was only for $\$ 10,000$ and its average income was $\$ 25,666$.

\subsubsection{Preliminary Analysis of the Life-Cycle Segments}

The life-cycle segments displayed an interesting distribution across Washington, Oregon, Idaho, and Montana. Of particular interest is the relative abundance of early families, newlyweds, single heads, and late families and the relative scarcity of retired couples and widows in Montana. A similar pattern is present in Idaho except the percentage of single heads is close to the relevant percentages in Oregon and Washington.

Other preliminary findings may be of interest to the manufactured housing industry. On average, over $63 \%$ of the manufactured homes purchased since 1984 have been used homes and about $37 \%$ have been new homes. Over $70 \%$ of the homes purchased by newlyweds, young males, and widows are used homes. The segments with the largest percentage of new-home purchases are the late families ( $52 \%$ new) and retired couples ( $45 \%$ new). On average, $70 \%$ of the new homes purchased since 1984 were purchased through a new mortgage and $30 \%$ were purchased with cash.

An interesting pattern appeared once the responses were segmented by the life-cycle segments. Approximately $67 \%$ of the new homes purchased by retirees were 
paid for with cash. This result should be of particular interest to the industry as it suggests that a majority of the retirees who purchase new manufactured homes may not be as price sensitive as is typically suggested. It also appears that a significant percentage (between $70 \%$ and $80 \%$ ) of retirees purchase used homes with cash.

These findings suggest that the concern about the impact that higher costs have on the market may be overstated for at least one market segment. These preliminary results suggest that most retirees pay cash when they purchase new manufactured homes; the source of the cash may well be the sale of their previous home. It may be that retirees who purchase new homes are not very price sensitive, especially if they have a large sum of cash on hand as the result of a recent house sale. Those who purchased used homes also paid cash a majority of the time. The reader should keep in mind that these are preliminary results and future research should explore this more fully.

\subsection{SEGMENTATION BY AREA OF DOMINANT INFLUENCE (ADI)}

As stated earlier, ADIs are geographic divisions defining television markets based on measurable viewing patterns. A utility marketing program should be able to collect information on energy users in each of the ADIs located in its service territory. When unique characteristics appear within an ADI, program developers might be able to use the information to tailor and target new programs or advertising campaigns to appeal to the energy users in a given ADI. This type of targeting would increase the effectiveness of conservation programs and the effective use of an advertising budget.

\subsubsection{Example ADls}

In the survey used to collect data for this study, information was collected from owner-occupied manufactured homes in 16 ADIs, most of which fall in Bonneville's service territory. The ADIs' relative population proportions are given in Table 4.2. The three largest ADIs were selected for the illustrative segmentation example appearing in the following section.

The three ADIs selected were numbers 105 (Seattle/Tacoma), 233 (Portland), and 337 (Spokane). Together they contain just over $83 \%$ of the manufactured home owners in Bonneville's service territory. 
TABLE 4.2. Relative Proportions of ADls

\begin{tabular}{|c|c|l||}
\hline $\begin{array}{c}\text { Percent of Sample } \\
\text { Population }\end{array}$ & $\begin{array}{c}\text { ADI Code } \\
\text { Number }\end{array}$ & Area Name \\
\hline 36.3 & 105 & Seattle/Tacoma \\
\hline 31.2 & 233 & Portland \\
\hline 6.6 & 337 & Spokane \\
\hline 5.2 & 237 & Medford \\
\hline 4.6 & 339 & Yakima \\
\hline 4.6 & 235 & Eugene \\
\hline 3.0 & 445 & Boise \\
\hline 2.3 & 295 & Idaho Falls/Pocatello \\
\hline 1.5 & 299 & Great Falls \\
\hline 1.4 & 342 & Missoula \\
\hline 1.3 & 457 & Billings/Hardin \\
\hline .9 & 613 & Butte \\
\hline .5 & 293 & Twin Falls \\
\hline .3 & 591 & Bend \\
\hline .3 & 297 & Helena \\
\hline .1 & 462 & $\begin{array}{l}\text { Minot/Bismarck/Dick- } \\
\text { enson/Glendive }\end{array}$ \\
\hline & & \\
\hline
\end{tabular}

\subsubsection{Demonstration of ADI-Based Segmentation}

The following section presents an example of how ADI-based segments might be used for future manufactured home programs aimed at the consumer. Eventually Bonneville's MAP program will end and a new program may replace it. Ideally such a program would have more of a market-pull orientation than the current MAP program. Programs designed in response to information learned from questioning potential customers about their preferences are more likely to have a market-pull orientation. 
Such programs are likely to achieve their goals through the natural forces of the market.

This demonstration of ADI-based segmentation relies on the responses of manufactured home owners to a question regarding their willingness to purchase $\$ 2,500$ worth of additional energy-efficient features for their manufactured home. The features were described to reduce their annual heating bills by $50 \%$ and the purchaser would receive a $\$ 1,250$ rebate.

Based on the home owners' responses, $67 \%$ of the manufactured home owners in the Seattle/Tacoma ADI indicated they would purchase the additional features. Only $60 \%$ of those in the Portland ADI and $52 \%$ in the Spokane ADI indicated they would purchase the features. Now suppose utilities were promoting a rebate-based conservation program in their service territory. Because the residents of the Seattle/Tacoma ADI appear to be more likely to respond to a rebate program, more television time should be purchased in the Seattle/Tacoma area for advertising the rebate program than in the other areas.

This simple example illustrates how ADI information might be used to target programs in Bonneville's service territory. It should be noted that the majority of the residents in each of the three ADIs were likely to purchase the features if they were offered a rebate. In this instance the ADI segments could provide information for a regional program that would support an allocation schedule for a region-wide advertising budget. 


\subsection{HOME OWNER PERCE'TIONS OF AFFORDABILITY}

As discussed earlier, tile respondents were asked to think back to their decision to purchase their current manufactured home and indicate how much influence several general purchase factors had on their purchase decision. The factors included the home's floor plan, the size of the home, the quality of the construction, and the home's energy efficiency, affordability, location, and amenities. Of these factors, affordability generally had the most influence on the home buyer's purchase decision. Even when the responses were segmented by the life-cycle segments as described in Chapter 4, affordability's influence was consistently ranked strongest for each segment.

\subsection{AFFORDABILITY CORRELATION ANALYSIS}

In an attempt to develop a better understanding regarding peoples' perceptions of affordability a correlation analysis was conducted using a set of economic factors that could influence the "affordability" of a home. Other variables such as the household's income at the time of purchase, the monthly principal and interest payment, the monthly lot rent, the average electric bill, and the annual heating bill were also used in the correlation analysis.

The general affordability variable had no strong correlations with any of the other variables used in the analysis. It appears that the influence that affordability has is so strong and uniform across all manufactured home owners that no clear relationships with other variables appear.

Although the strength of the correlations was low, it was informative to find that affordability's influence on the purchase decision was negatively correlated with income, principal and interest payments, monthly lot rent, the home's purchase price, and the average electric bill. Thus, the results suggest that as income decreases the influence of affordability increases. Similarly, lower monthly mortgage payments are correlated with a higher influence of affordability. Also, when the purchase price of the manufactured home increases, the influence of affordability decreases. All these results are intuitive assuming that those who have lower incomes are going to be more concerned about affordability, and they will also want to pay smaller monthly mortgage payments and other monthly payments. 
The analysis showed that the influence on a home's affordability associated with the mortgage interest rate was positively correlated with the influences associated with the down payment, the monthly mortgage payment, and the loan's term. The analysis also found that, as purchase price increases, the influence of the loan's interest rate decreases. This relationship holds also for monthly lot rent increases. Again these results make intuitive sense. It would be expected that influences associated with financial variables or factors would be correlated. It would also be expected that as a home's purchase price rises, the influence of affordability decreases: those who purchase more expensive homes are less likely to be concerned about affordability.

\subsection{AFFORDABILITY'S INFLUENCE ACROSS LIFE-CYCLE SEGMENTS}

The home owner's responses to the questions about the strength of influence each cif the general factors had on their purchase decision were segmented by the life-cycle segments. This ivas also done with the questions about the economic factors that can help deiermine whether or not a home is affordable. The rest of this section follows discussions of the results of the segmentation.

Affordability iad ihe strongest influence on the purchase decision of any of the general factors for all the life-cycle segments except the retired couples segment. This segment's highest average rank went to the home size factor, followed by the floor plan/layout factor. Affordability had the third highest average influence rating in this segment. For the other segments this order was generally reversed, with affordability first and the home size and floor plan/layout factor following.

The responses to the questions about the influence various economic factors had on determining whether or not the home buyer could afford the home were examined by the life-cycle segments. In general, the home's total purchase price had the strongest average influence rating. Each lifz-cycle segment except widowers placed the highest average rating on the home's total purchase price. From there groups of segmeits exhibited some similar res:ponse patterns, although few similarities were presenic across all segments.

For exarnple, households in the newlywed and young family segments rate the down payment and the mortgage length or mortgage interest rate as the next two most important factors affecting their ability to afford their home. This result is not surprising when one considers the sias 2 of the life-cycle these households are in. Older households have had a longer time to generate a pool of funds for a down payment. This may also help explain why the households in the newlywed, young 
family, and young male segments visited, on average, the highest number of lenders when they arranged their own financing. The data suggest they may have visited several lenders either looking for a lender with a small down payment requirement or because, without a long credit history, they had difficulty securing a loan.

The single head and late family segments indicated that the second most influential economic factor following total purchase price was the length of the mortgage. These households are further along in their life cycle and have had more time to generate the funds needed for their down payment so they appear to focus on one of the other economic factors associated with their financing.

In general, it appears that households headed by younger people (those under 40 years of age) indicated factors associated with financing had more influence on determining whether a home was affordable to them. The data also suggest that households headed by older people (those over $\mathbf{4 0}$ years of age) were more affected by other factors such as monthly utility bills, energy costs, and expected maintenance costs. ${ }^{(\mathrm{a})}$

(a) This may be because older people who are more likely to be on fixed incomes are more concerned about costs that have the potential for increasing substantially in the future. 


\subsection{ENERGY-EFFICIENT MANUFACTURED HOME AFFORDABILITY INDEX}

This chapter contains a discussion of how the manufactured home affordability indexes proposed in Sandahl et al. (1992) might be affected by the findings in this study. The information from lenders, appraisers, and dealers presented in that study indicated that the affordability of energy-efficient manufactured homes is determined in part by whether lending practices take the benefits of energy efficiency into account. Energy-efficient homes usually have a higher purchase price than comparable less efficient homes; the economic benefits to buyers of energy-efficient homes show up in reduced utility bills. One key to making energy-efficient homes affordable is to recognize these benefits in the lending process. The following sections include a brief review of the affordability indexes proposed in Sandahl et al. (1992) and a discussion of the implications this study's findings might have for those indexes.

\subsection{REVIEW OF MANUFACTURED HOUSING AFFORDABILITY INDEXES}

In Sandahl et al. (1992) two affordability indexes were proposed following the basic approach of the National Association of Realtors' affordability index. The index is designed to measure the degree to which a "typical" middle-income family can afford the mortgage payments on the "typical" home. Our indexes were modified to reflect manufactured home lending practices and to recognize differences in the energyefficiency levels of manufactured homes. Our indexes proposed to recognize the differences in energy efficiency through adjustment of the "housing expense-to-income" ratio. This ratio is commonly used by lending institutions to determine how large a loan a household can handle based on its income. As a result of the significant differences between the loan terms associated with home-land loans and home-only loans, we proposed two individual affordability indexes. One index is for home-only purchases while the other is for home-land purchases.

Both indexes included values for median household income, loan term, interest rate, down payment percentage, and housing expense/income ratio. The home-only index used the same median household income amount used in the home-land index. That is where the similarity ends. The home-only index's loan term was set at 20 years as opposed to 30 years for the home-land index. The home-only index included a monthly lot rent fee that the home-land index did not have. The new home prices differed between the two because the home-land index included a $\$ 10,000$ lot value. The home-land index had a lower interest rate but a larger percentage down payment. 
Both indexes used these terms to calculate a "typical" monthly payment, which was then multiplied by the maximum housing expense multiplier to determine the monthly income required to make the "typical" monthly payment. For home-only loans the median lot rent and median monthly mortgage insurance payments were added to the monthly loan payment. The typical monthly income figure was then multiplied by 12 to determine what the annual qualifying income requirement would be to purchase the "typical" manufactured home. The final calculation in each index involves dividing the median household income by the median annual qualifying income and multiplying the result by 100 . This final calculation generates an index score; if the index score equals 100 then the median household income can just qualify for the median priced home. If the score is over 100 the median household income can qualify for more than the median priced home (affordability increases) and if the score is under 100 the median priced home is out of reach of the median household income (affordability decreases).

Each of the indexes was calculated for a standard home and a home built to Super Good Cents (SGC) program requirements. The difference between the two calculations was the value used for the maximum housing expense/income ratio. For the standard home the ratio was 0.28 , and for the SGC home the ratio was "stretched" up to 0.308 to reflect the higher efficiency and lower utility bills of the home. For a complete explanation of the logic behind this stretched value the reader should refer to Chapter 5 in Sandahl et al. (1992). The next section contains a discussion of how the results of this study might affect the proposed indexes.

\subsection{SURVEY RESULTS AND THE AFFORDABILITY INDEXES}

To get a clearer picture of current lending practices facing the new manufactured home buyer, the survey respondents who purchased a new home since 1985 were used in the analysis that supports this chapter. These respondents were further segmented based on where their home was sited (e.g., on their own land, in a manufactured home park, or on someone else's land). Those whose homes were on their own land were assumed to have gotten home-land loans while the others were assumed to have taken out home-only loans. Results of the analysis revealed that the median loan amount for the home-only purchasers was $75 \%$ of the price of the home, indicating a $25 \%$ down payment requirement; however, the median down payment percentage given for this group was $10 \%$. As a result of this discrepancy, only the home-land index will be recalculated in this report. Future research should attempt to determine the source of discrepancy. 
The median income for the home-land index was increased from $\$ 22,000$ as listed in Sandahl et al. (1992) to $\$ 29,500$ for a standard manufactured home based on the survey results. The median loan term was reduced from 30 years to 20 years. The lot price was increased from $\$ 10,000$ to $\$ 14,500$. Thus, the home and lot price is now $\$ 52,436$ as opposed to $\$ 48,200$. Based on the survey data for home-land purchasers of new homes, we use a down payment of $20 \%$, consistent with the value used in the previous study. The revised index calculation generates a higher affordability index score than the previous version. This is due largely to the higher median income that was used. The higher income figure swamped the negative effects that the higher interest rate, shorter loan term, and higher lot and home prices had on the affordability index score.

Even without modifying the housing expense/income ratio for SGC homes, as was done in the original study, SGC homes would still have a high affordability index score of 161 . The annual qualifying income only increases to $\$ 18,335$ for the typical SGC home when the standard expense/income ratio is applied. By looking at the survey income distribution data for those who purchased new homes sited on their own property, it appears that about $15 \%$ of this group's incomes fall below the median qualifying income for a typical standard manufactured home and about $17 \%$ would fall below the median qualifying income for SGC homes without the modified housing expense/income ratio.

If the modified expense/income ratio is applied for SGC homes, the energyefficient homes become more affordable as shown in the previous study. The reader should note that these are preliminary analyses, and that the sample size does not allow for conclusive findings at this point. However, the data do suggest that, in general, new-home buyers who plan to site their homes on their own property should easily be able to afford the added cost associated with a SGC home. Table 6.1 shows the results of the revised home-land affordability index calculation and reflects the expense/income ratio stretch for energy-efficient homes.

\subsection{KEEPING ENERGY-EFFICIENT HOMES AFFORDABLE}

Sixty-nine percent of the respondents who purchased new homes since 1985 financed the home through a new mortgage, and $31 \%$ paid for their home with cash. This result suggests that nearly one-third of the new-home buyers are not very sensitive to the cost of the manufactured home. Future research should attempt to 
identify who these people are. The split between home-land and home-only purchasers in this group was approximately even with $51 \%$ siting their homes on their

TABLE 6.1. Home-Land Affordability Index Values

\begin{tabular}{||l|c|c||}
\hline \multicolumn{1}{|c|}{ Factor } & Standard Home & SGC Home \\
\hline Median Household Income & $\$ 29,500$ & $\$ 29,500$ \\
\hline Loan Term & $20 \mathrm{yrs}$ & $20 \mathrm{yrs}$ \\
\hline Lot Price & $\$ 14,500$ & $\$ 14,500$ \\
\hline Home + Lot Price & $\$ 52,436$ & $\$ 55,436$ \\
\hline Interest Rate & $10 \%$ & $10 \%$ \\
\hline Down Payment & $20 \%$ & $20 \%$ \\
\hline Housing Expense/Income Ratio & .28 & $.308(2.8 \%$ \\
& & $\$$ stretch) \\
\hline Loan Amount & $\$ 41,948$ & $\$ 44,348$ \\
\hline Monthly Loan Payment & $\$ 405$ & $\$ 428$ \\
\hline Maximum Housing Expenditure Multiplier & $(1 / 0.28)$ & $(1 / 0.308)$ \\
& 3.57 & 3.25 \\
\hline Monthly Qualifying Income Required & $\$ 1,446$ & $\$ 1,391$ \\
\hline Annual Qualifying Income Required & $\$ 17,352$ & $\$ 16,692$ \\
\hline (Median Household Income)/(Annual & 170 & 176 \\
Qualifying Income) * 100 = Affordability & & \\
Index & & \\
\hline
\end{tabular}

own property and $49 \%$ siting their home in a park or on someone else's property. Seventy-eight percent of the home-land purchasers financed the purchase with a new mortgage, while $22 \%$ paid cash. Only $59 \%$ of the home-only purchasers financed their purchase with a loan and $41 \%$ paid cash. This result and the findings regarding the life-cycle segments suggest that a large portion of new home-only purchasers are cash-paying retirees. A home's affordability is important to these people but the factors that affect affordability are less influenced by purchase price and lending terms than younger households who have to finance their purchase. 
The respondents who financed their home through a new mortgage were asked to identify the loan feature that had the most influence on their choice of mortgage. Their responses were segmented by whether they were home-land purchasers or home-only purchasers. Forty-six percent of the home-land purchasers said the loan's interest rate was the key factor in their loan choice, $24 \%$ said it was the monthly payment, and $7 \%$ said it was the down payment. Only $3 \%$ of this group of respondents said the debt- (housing expense) to-income qualification ratio had the most influence on their choice of mortgage. A smaller percentage of the home-only purchasers said the loan's interest rate had the most influence, but at $29 \%$ it was the largest single influence. Twenty-seven percent of the home-only purchasers said the monthly payment had the most influence, $13 \%$ said it was the down payment, and $11 \%$ said it was the length of the loan. Only $4 \%$ of this group of purchasers indicated the housing expense-to-income ratio had the most influence in their loan selection.

Along with the economic affordability factors, the respondents were asked about the influence the monthly mortgage payment had on their affordability determination. The monthly mortgage payment was found to have a strong influence on a manufactured home buyers' determination of a home's affordability, especially for younger households. However, because different loan terms such as the interest rate, the total purchase price, and the length of the mortgage all affect the size of the monthly payment, it was left out of the analysis up to this point.

Each of the terms listed above can be used to modify (reduce) the monthly payment. Because the monthly payment was found to be influential, it may be better to look for ways to reduce the monthly payment rather than increase the monthly payment, which tends to be the result when the housing expense/income ratio is modified. Manipulation of the loan terms should be explored as an alternative to modifying the housing expense-to-income ratio to maintain the affordability of manufactured homes. This strategy is consistent with the empirical results in Kavanaugh et al. (1993) demonstrating the importance of interest rates and monthly payments on consumer demand. 


\subsection{FINDINGS AND CONCLUSIONS}

The following findings and conclusions are based on the responses of the 1,106 manufactured home households participating in this study and information from prior related studies. In general, this study has focused on the influence that general purchase factors (e.g., affordability, home size, and energy efficiency), economic affordability factors (e.g., interest rates, total purchase price, and utility bills), and home features (e.g., window area, additional insulation, and attractive floor coverings) have on the purchase decision of the different sub-groups of manufactured home buyers discussed throughout the report. The findings and conclusions are presented by topic and issue area. Implications of the findings and conclusions are relevant to future programs in the region and elsewhere in the United States. Implications and recommendations appear in Chapter 8.

\subsection{OCCUPANT CHARACTERISTICS}

The first issue this report addressed was development of a regional profile of the manufactured home household and state-by-state comparisons. The key findings include these:

- The average age of the head of household for the region was 53. Washington and Oregon manufactured home owners were older than their counterparts in Idaho and Montana.

- Contrary to prevalent views, the age distribution of manufactured home owners is not dominated by the young and old. About one-third of the manufactured home owners are under 40 years of age, one-third are between 40 and 65, and one-third are 65 or older.

- The manufactured home-owning population in Idaho and Montana have lower incomes than their counterparts in Washington and Oregon.

Buyers of new homes and used homes were compared:

- We found no difference in the average age of the household heads in new and used manufactured homes.

- We found no difference in the average size of the households in new and used manufactured homes. 
- Used-home buyers had incomes about $20 \%$ less than new-home buyers.

- Twenty-four percent of the new-home buyers and $38 \%$ of used-home buyers were first-time buyers.

- Seventy-nine percent of new-home buyers and $51 \%$ of used-home buyers had owned their previous residence.

\subsection{MANUFACTURED HOME CHARACTERISTICS}

The survey data provided important information about the manufactured homes purchased in the region and where they were sited.

- Thirty-six percent of the homes purchased since the end of 1984 were new homes and $64 \%$ were used homes: nearly two-thirds of all manufactured homes purchased were used homes.

- About one-fourth of all the manufactured homes purchased since the end of 1984 were built in 1974 or earlier.

- Regionally, $66 \%$ of the manufactured homes in the survey sample heat primarily with electricity; however, over half in Idaho and Montana reported using some other primary heating fuel (natural gas, propane, or wood).

- The average annual cost to heat a manufactured home in the Pacific Northwest, based on occupant estimates, was \$630; Washington residents reported the highest cost at $\$ 684$, and Oregonians reported the lowest at $\$ 601$.

- The new-home buyer's median annual heating bill was $\$ 508$ while the usedhome buyer's median annual heating bill was $\$ 600$, suggesting that newer homes are more energy-efficient.

- Ninety-six percent of the new homes purchased in the region were purchased from dealers; on the other hand, only $12 \%$ of the used homes were purchased from dealers and $64 \%$ were purchased from a private party.

- About half of the new homes purchased since 1984 have been located on the owners' own land, while $53 \%$ of used manufactured homes were sited in a manufactured-home park and only $36 \%$ on the buyer's own land. 


\subsection{FACTORS IN THE PURCHASE DECISION}

A great many factors enter into the manufactured home purchase decision. We examined general factors (e.g., affordability, home size, and energy efficiency), specific home characteristics (e.g., window area, additional insulation, and attractive floor coverings), factors affecting affordability (e.g., interest rates, total purchase price, and utility bills), and financing issues (e.g., how the home was financed and the financing terms). This section presents the key findings related to the first two types of factors; findings on affordability and financing are presented in following sections.

The key findings on general purchase factors and home features that were identified in this study include these:

- Of the general purchase factors, affordability had the highest average influence rating both at the regional level and across the four states.

- Of the home features, the number of windows/window area, followed by an efficient heating and cooling system, were the most influential features on a regional and state-by-state basis.

Key differences were identified between what factors influenced buyers of new and used manufactured homes:

- New-home buyers said the most influential general purchase factor was the home's floor plan, followed by its affordability. The used-home buyers said affordability was the most influential factor.

- The new-home buyers were more influenced than the used-home buyers by the home's floor plan, size, construction quality, energy efficiency, and aesthetic appeal.

- Used-home buyers were much less influenced than new-home buyers by the home's energy efficiency.

- New-home buyers rated the influence of almost all the home features considerably higher in their purchase decision than used-home buyers did. 


\subsection{FINANCING THE PURChASE OF MANUFACTURED HOMES}

This study provided extensive information about how buyers of both and new and used homes finance the purchase of their manufactured home. Findings for all buyers combined included the following:

- For buyers who took out a loan, dealers arranged the loan or provided the lender for $49 \%$ of them.

- Thirty-six percent of all buyers who took out a loan arranged their own loan without the dealer's direct involvement.

- Of the buyers who arranged their own loans, less than $10 \%$ contacted three or more lenders.

- The median loan amount for the region was $\$ 25,500$. The median amounts were much higher in Washington and Oregon than in Idaho and Montana.

- The median loan term length for the region was 15 years; this was also the median loan term in Washington and Oregon. However, the median loan term was only 10 years in Idaho and only 8 years in Montana.

- The region's median down payment was $10 \%$; this was also the case in each state except Montana where the median down payment was $12 \%$.

- The current median interest rate on manufactured home loans in the region was $10.9 \%$. It ranged from a low of $10 \%$ in Oregon and Idaho to a high of $12 \%$ in Montana.

- The interest rate on a mortgage was the loan characteristic that had the most influence on the manufactured home buyers' selection of a mortgage.

There were several differences in the financing statistics for new and used manufactured homes:

- For new-home buyers only, almost $72 \%$ had their loan arranged by the dealer or the dealer recommended a lender. For used-home buyers, the comparable figure was only $29 \%$. 
- Only $26 \%$ of new-home buyers arranged their own loan, whereas $34 \%$ of usedhome buyers did so.

- Thirty-percent of all new manufactured homes were purchased with cash and the remaining $70 \%$ were financed with a loan. Only $38 \%$ of the used-home buyers took out a mortgage.

- The median loan amount was $\$ 34,600$ for new homes and $\$ 18,500$ for used homes.

- The median loan length was 20 years for new-home loans; it was 13 years for used-home loans.

- The median down payment was $10 \%$ for both new and used homes.

- The interest rates for loans on new homes were slightly higher than for loans on used homes.

\subsection{AFFORDABILITY OF MANUFACTURED HOMES}

A major purpose of this study was to clarify what factors buyers believe determine the affordability of manufactured homes. The findings here complement previous analytic results derived from a study of lenders and appraisers (Sandahl et al. 1992). The importance of focusing on this issue with buyers was validated by the large emphasis survey respondents placed on affordability when queried about general factors affecting their purchase decision. The key findings from this study about buyers' perceptions of affordability follow:

- Of the economic factors affecting affordability, the home's total purchase price has the most influence on the home buyer's determination of affordability. This was true at the regional level and in each state.

- Utility bills or long-term energy costs have the second largest influence on affordability.

- New-home buyers tend to rate all the economic affordability factors as more important than used-home buyers do. 
- Using an "affordability index," the typical buyer of a median-priced, standardefficiency new manufactured home plus land has an income $70 \%$ beyond what is required under standard loan qualification requirements. Only about $15 \%$ of potential buyers of homes under these conditions have incomes below the amount required to qualify for a loan.

- Because lending practices and economic factors do appear to vary across states, it may be appropriate to determine affordability on a state-by-state basis.

Manufactured-home programs in the Pacific Northwest focus on energyefficiency improvements. Because higher energy efficiency usually entails increased first costs and all buyers consider purchase price a major determinant of affordability, efforts to increase energy efficiency can impact affordability. This study's results show that, although affordability is highly dependent on first cost (purchase price), buyers take into account 1) other economic factors that depend on energy efficiency and 2) financial factors when assessing affordability. The following general findings about energy efficiency and affordability were provided by this study:

- Without changing loan qualification ratios, energy-efficient manufactured homes (such as SGC homes) are also very affordable, with only about $17 \%$ of potential buyers falling below the median qualifying income. A typical buyer purchasing the home and land through a combination loan should easily be able to afford the added cost associated with an SGC home.

- If lenders stretched the loan qualifying ratio to reflect expected utility bill savings, the affordability of SGC homes would increase about $10 \%$ (i.e., the affordability index increases by about $10 \%$ ).

- $\quad$ Sixty-two percent of buyers would have purchased extensive energy-efficiency features if offered a rebate equivalent to half the added cost; $50 \%$ would have purchased the measures if offered a 5-year, no-interest loan; and $35 \%$ would have purchased them if the lender had stretched the loan qualification ratio.

\subsection{MARKET SEGMENTS}

For program and market targeting purposes, it is useful to identify relatively homogeneous market segments. Several segmentation approaches were examined in this study. The findings for three segmentation schemes are presented in this section. 


\subsubsection{Home-Land and Home-Only Purchasers}

One way to segment buyers is according to whether they purchased their manufactured home for placement on 1) their own land or 2) land owned by someone else. We refer to the former group as home-land purchasers (HLS) and the latter group as home-only purchasers (HOs). This distinction was felt to be important because home-land purchase situations are more like site-built home purchases. Consequently, an argument can be made that lenders should offer loan terms to HLS that are similar to the terms they extend to site-built home buyers. The key findings related to this segmentation are presented below:

- HLs tend to have younger household heads and larger households.

- HLs are more affluent than HOs.

- There were no significant differences in how the two groups rated the influence of the general purchase factors (such as affordability and home size) in their purchase decision.

- HLs considered the economic affordability factors (such as interest rate and down payment requirement) associated with a mortgage to be much more important than HOs did in their purchase decision.

- $\quad$ Although siting a manufactured home on the buyer's own property makes it quite similar to a site-built home, manufactured home buyers classified as HLS do not appear to be obtaining financing terms comparable to those for site-built housing.

\subsubsection{Life-Cycle Market Segments}

A second segmentation approach was applied. Life-cycle market segments were determined for the manufactured home market in the Pacific Northwest. These segments categorize households according to their life-cycle characteristics. This segmentation scheme is often used in marketing programs because distinct life-cycle segments have common demographic characteristics that can be linked to different marketing strategies. Our findings using this segmentation technique follow:

- Twelve distinct life-cycle segments emerged based on the responses of the households. 
- Young families (i.e., those families where the household head is less than 40 years old) represent the largest single segment with about $23 \%$ of the population.

- Although used manufactured homes purchased in the region outnumber new homes purchased by nearly two-to-one, mernbers of two life-cycle segments buy a relatively large proportion of new homes: late families $(52 \%$ new homes and $48 \%$ used homes) and retired couples (45\% new homes and $55 \%$ used homes).

- Approximately $67 \%$ of the new homes purchased by retirees were paid for with cash. Similarly, between $70 \%$ and $80 \%$ of the retirees purchasing used homes paid for them with cash.

- Although affordability was the most influential general purchase factor overall, the retired couples segmeint rankerl it behind home size and floor plan.

- The different segments consider affordability to be driven by different factors. Household segments headed by younger people (e.g., newlyweds, young fa inilies, young males, and young females) indicated that factors associated with financing had more influence on their affordability determination than did older households. Older households, which were more likely to pay cash for a home, saw affordability in terms of monthly maintenance and energy costs.

\subsubsection{Geographic Areas of Dominant Influence}

The final segmentation approach investigated was the use of Areas of Dominant Influence (ADIs), which are geographic divisions that define television markets. This approach was examined only very briefly because it was not a main focus of this study. Preliminary findings included the following:

- $\quad A D I$ segmentation could provide useful information for allocating a television advertising budget across the region.

- $\quad A D I$ segmentation could be useful for identifying and selecting promotional campaign content. 


\subsection{RECOMMENDATIONS}

The findings from this study suggest that energy-efficient manufactured homes are very affordable for typical buyers in the Pacific Northwest under current market conditions. Nevertheless, large numbers of buyers have not traditionally purchased highly efficient manufactured homes without the influence of regional conservation programs and incentives. In addition, nearly $20 \%$ of potential buyers would not qualify for a loan on a highly efficient home if lenders used their standard loan qualification criteria. For the region to continue to benefit from improved energy efficiency in the manufactured housing sector, even after current programs end or change, several steps need to be taken to encourage buyers to demand energy efficiency.

This chapter presents recommendations aimed at resolving remaining impediments limiting buyer purchases of energy-efficient manufactured homes or efficiency upgrades of existing homes. They are based on the extensive data from buyers gathered from our regional survey. Most of the recommendations are addressed to Bonneville; however, successful long-term shanges in the marketplace will require the full cooperation of manufacturers, dealers, lenders, and utilities. They are organized into the following topic areas: existing homes, lending practices, program actions, and research needs.

\subsection{UPGRADING THE EFFICIENCY OF EXISTING MANUFACTURED HOMES}

Because nearly two-thirds of the manufactured homes purchased each year in the Pacific Northwest are used homes and many are older, inefficient homes, a large potential exists for improving energy efficiency in this housing sector by influencing buyers who shop for used manufactured homes. We make the following recommendations regarding used manufactured homes:

1) Bonneville and others in the region designing and conducting programs for used manufactured homes should tailor such programs to reflect the characteristics of buyers who purchase those homes and the characteristics of the typical homes purchased. For example, used manufactured home buyers have relatively low incomes and nearly $\mathbf{4 0 \%}$ are first-time home buyers. About $40 \%$ of the used homes were built in 1974 or earlier, nearly two-thirds were purchased from private parties, and about half were sited in a manufactured-home park. 
2) The amount of energy used to heat older manufactured homes should be verifled with fleld data. Households participating in this study estimated that, on average, older manufactured homes cost about $\$ 600$ annually to heat; this is approximately $20 \%(\$ 100)$ more per year to heat than newer manufactured homes. These estimates should be validated and the information should be provided to utilities, lenders, and potential buyers.

3) Bonneville and others should explore ways to encourage prospective used manufactured home buyers to buy newer, more energy-efflclent homes instead. Possible mechanisms might Include utility rate Incentlves, down payment rebates, or favorable lending terms.

\subsection{LENDING PRACTICES}

The affordability of energy-efficient manufactured homes is highly dependent on the loan terms established by the lending industry. Seventy percent of new manufactured homes are financed with a loan. To improve the ability of buyers to purchase energy-efficient manufactured homes, the following steps should be taken:

4) Lending institutions should take Into account that almost half (49\%) of the new manufactured homes purchased since 1984 have been sited on the owner's own property, many of them on permanent foundations, making them very similar to site-built homes. Bonneville should encourage lender practices that are providing site-built type loan terms to home-land purchasers, especially for energy-efficient manufactured homes.

5) Bonneville should focus its efforts with the lending community on reducing the down payment requirements and interest rates for mortgages for energy-efficient manufactured homes because these loan characteristics tend to have the most influence on the buyers' loan choice.

6) Because energy-efficient manufactured homes reduce monthly operating costs and, consequently, the risks of default or delinquency, lenders should reduce the interest rate or down payment required on manufactured home loans. As noted above, these two factors were generally the most influential in the home buyers' loan selection and could be the most effective tools for encouraging purchases of energy-efficient manufactured homes. 
7) Lenders should modify the loan qualification expense/income ratio to account for the reduction in monthly utility bills associated with energy-efficient manufactured homes. Stretching this ratio for energy-efficient manufactured homes could alleviate the barrier faced by some of those buyers who are unable to qualify for loans on such homes simply because the purchase price is increased by the energy-efficiency features added to the home.

\subsection{PROGRAM ACTIONS}

To make sure that energy-efficiency improvements continue in manufactured homes produced in the Pacific Northwest, Bonneville, utilities, and others need to reflect the findings from this study in future program activities. Two themes emerge prominently from the study results: first, making energy-efficient manufactured homes affordable to potential buyers requires a joint effort involving all market participants, and the lending community needs to be brought into future programs; second, the needs of specific buyer groups must be recognized in future programs and programs must be designed to provide options that will appeal to different market segments. We recommend the following actions:

8) Bonneville should involve manufactured housing lenders in the design and implementation of future energy-efficiency programs. The results of this study and others should be used as the basis for developing future programs. A workshop involving lenders and other key program participants should be conducted to inform lenders about past programs and to begin a joint effort.

9) Future programs should reflect the information and findings here about different manufactured home buyer segments and should incorporate different options that can be offered to different types of buyers. For example, future programs should take into account that older buyers are more likely to pay cash for their home and thus are more likely to respond to programs that affect out-of-pocket costs rather than loan characteristics. 


\subsection{RESEARCH NEEDS}

Analysis of the survey data collected for this study was limited by the specific objectives of the study and scope limitations. We recommend that further analyses be conducted, both with the existing data and on additional topics identified by this research.

10) The existing survey data should be further analyzed to explore factors that affected buyers' loan shopping behavior; comparisons between buyers who financed and those who paid cash for their homes; characteristics of first-time buyers; characteristics of buyers who purchased energy conservation measures (ECMs); and characteristics of buyers who responded favorably to a rebate, a no-interest loan, or improved loan qualification criteria for ECMs.

11) Bonneville and others should conduct research to determine why loan shopping behavior (number of lenders visited) differs across the life-cycle segments and investigate methods to encourage potential buyers to shop around for better loan terms. Sandahl et al. (1992) showed that lending terms vary considerably across manufactured home lenders and buyers can benefit from shopping for better terms.

12) Focus groups should be conducted with members of each life-cycle segment to get a better understanding of how their purchase decisions differ. These focus groups should determine what features to include in a program aimed at reducing the financial barriers associated with purchasing a new, energy-efficient manufactured home.

Partly because of its primary focus on affordability, this study has concentrated on economic issues of the manufactured home purchase process, yet consumer choice is determined by other factors as well. Improved understanding of the role energy efficiency plays in determining home heating and cooling costs and increased confidence in estimates of utility bill savings will be essential to convince buyers to make added investments in energy efficiency. Furthermore, long-term behavioral and attitude changes will require manufactured home buyers to become better informed about all the benefits of reduced energy usage. We recommend the following research activities to address these issues: 
13) Bonneville should analyze data collected in previous regional studies to identify tiers or groups of manufactured home buyers who are more responsive to energy conservation programs. Previous studies have identified tiers of households that have different commitments to energy conservation (see Fang 1985, for example), but this past research did not focus on manufactured home occupants.

14) Bonneville should conduct new studies to identify key market segments for targeting future programs to different types of manufactured home buyers. Information from such studies should be combined with the information collected for this study to segment buyers for marketing purposes.

15) Bonneville should convene a meeting with key organizations in the Pacific Northwest and nation to review the Information currently avallable on manufactured home buyers and to develop a consensus on a menu of program options for promoting the purchase of energy-efficient manufactured homes. The meeting should a) identify what is already known about buyers, b) Identify important information gaps, c) develop a research agenda, and d) begin formulating a set of program options. 


\subsection{REFERENCES}

Fang, J. M. 1985. Household Attitudes Toward Energy Consenvation in the Pacific Northwest: Overview and Comparisons, PNL-5405, Pacific Northwest Laboratory, Richland, Washington.

Kavanaugh, D. C., D. M. Anderson, T. L. Marsh, A. D. Lee, and S. A. Onisko. 1993. Affordability and Energy Efficiency in the Demand for Manufactured Housing: An Empirical Analysis, (forthcoming), Pacific Northwest Laboratory, Richland, Washington.

Onisko, S. A. 1989. Dealer Participation in the Bonneville Power Administration Manufactured Housing Residential Construction Demonstration Project, Bonneville Power Administration, Portland, Oregon.

Sandahl, L. J., M. P. Hattrup, A. D. Lee, and S. A. Onisko, 1992. Energy-Efficient Manufactured Homes: The Role of Lending and Appraisal Practices, PNL-8319, Pacific Northwest Laboratory, Richland, Washington. 
APPENDIX A

LIFE-CYCLE SEGMENT DEVELOPMENT 


\section{APPENDIX A}

\section{LIFE-CYCLE SEGMENT DEVELOPMENT}

Twelve life-cycle segments were developed in a series of steps that used the household demographic characteristics to create groups of similar households. The steps are discussed below.

The first step used the employment status variables of the female (FEMP) and male (MEMP) household heads to create a new variable (WORK). The new variable categorized the households into eight groups. FEMP and MEMP each had five values $^{(\mathbf{a})}$, which are listed in Table A.1.

TABLE A.1. Values for Variables FEMP and MEMP

\begin{tabular}{|c|l|}
\hline Value & Definition \\
\hline 0 & No Answer \\
\hline 1 & Working Full Time \\
\hline 2 & Working Part Time \\
\hline 3 & Retired \\
\hline 4 & Not Employed \\
\hline
\end{tabular}

The employment variables were used to segment the households into eight groups represented by the eight values of the new variable WORK. Table A.2 illustrates how WORK was created and Table A.3 defines each value for WORK.

(a) In addition to the five values of FEMP and MEMP, missing values were used in the creation of the variable WORK. In cases where a home did not have a male or female head of household, then FEMP or MEMP would have a missing value. 
TABLE A.2. Creation of the Variable WORK

\begin{tabular}{|c|c|c|c|c|c|c||}
\hline \multirow{2}{*}{ FEMP } & \multicolumn{7}{|c||}{ MEMP } \\
\cline { 2 - 7 } &. & 0 & 1 & 2 & 3 & 4 \\
\hline \hline &. & $W=0$ & $W=5$ & $W=5$ & $W=2$ & $W=2$ \\
\hline 0 & $W=0$ & $W=3$ & $W=6$ & $W=7$ & $W=3$ & $W=3$ \\
\hline 1 & $W=4$ & $W=6$ & $W=6$ & $W=6$ & $W=6$ & $W=6$ \\
\hline 2 & $W=4$ & $W=7$ & $W=6$ & $W=6$ & $W=7$ & $W=7$ \\
\hline 3 & $W=1$ & $W=3$ & $W=6$ & $W=7$ & $W=3$ & $W=3$ \\
\hline 4 & $W=0^{(a)}$ & $W=3$ & $W=6$ & $W=7$ & $W=3$ & $W=0$ (b) \\
\hline (a) & $\begin{array}{l}\text { Some of the households occupied by females who stated they were not } \\
\text { employed (FEMP = 4) were grouped with those who said they were retired } \\
\text { WORK = 1) because they were older and living alone. } \\
\text { Some of the households where both the male and female head of household } \\
\text { said they were "Not Employed" (FEMP and MEMP = 4) were grouped with } \\
\text { retired couples (WORK = 3) because they were 60 years or older. }\end{array}$ \\
(b) \\
\hline
\end{tabular}

TABLE A.3. Values and Definitions for the Variable WORK

\begin{tabular}{|c|l|}
\hline Value & Definition \\
\hline \hline 0 & No Working Household Head \\
\hline 1 & Single Retired Females \\
\hline 2 & Single Retired Males \\
\hline 3 & Retired Couples \\
\hline 4 & Single Working Women \\
\hline 5 & Single Working Men \\
\hline 6 & Couple with at Least One Working Full Time or Two Part Time \\
\hline 7 & Couple with at Least One Working Part Time \\
\hline
\end{tabular}


The second step involved the creation of two new variables. Once the households were segmented by employment status and living arrangement (e.g., not employed, retired, working, single household head, or couples) the households were further segmented by the age of the household heads and the existence of children. In order to determine if children were in a household a new variable had to be created. A new variable "KIDS" was created by adding up the number of children under 20 years old in a given household. The number of children in the household did not play a role in the segmentation scheme, only the presence or lack of children.

The third step uses the new variable KIDS and the variable WORK and the household age variable (HAGE) to segment the households into 12 groups. The values for HAGE are defined in Table A.4.

TABLE A.4. Values and Definitions for the Variable HAGE

\begin{tabular}{|c|l||}
\hline Value & \multicolumn{1}{|c|}{ Definition } \\
\hline \hline 1 & Family - Female, if Present, Under 30 Years Old \\
\hline 2 & Family - Female, if Present, 30-39 Years Old \\
\hline 3 & Family - Female, if Present, 40-49 Years Old \\
\hline 4 & Family - Female, if Present, 50-59 Years Old \\
\hline 5 & Family - Female, if Present, 60 Years Old and Over \\
\hline 6 & Non-family - Male Under 35 \\
\hline 7 & Non-family - Male 35 and Over \\
\hline 8 & Non-family - Female Under 35 \\
\hline 9 & Non-family - Female 35 and Over \\
\hline
\end{tabular}

In the final step, the combination of the three variables provided the basis for the new life-cycle variable (LC) that groups the households into 12 categories. The 12 separate life-cycle segments are shown in Table A.5.

The reader should note that less than $1 \%$ of the households were headed by household heads that were not employed. Because this was a small percentage of the total, these households were dropped out of the life-cycle segments. 
TABLE A.5. Values and Definitions for the Variable LC

\begin{tabular}{|c|l||}
\hline Value & Definition \\
\hline 1 & Young Couples without Children (Newlyweds) \\
\hline 2 & Young Couples with Children (Early Families) \\
\hline 2.5 & Single-Parents with Children (Single Heads) \\
\hline 3 & Older Couples with Children (Late Families) \\
\hline 4 & Working Single Males Under 40 Years Old (No Children) (Young Males) \\
\hline 5 & $\begin{array}{l}\text { Working Single Females Under } 40 \text { Years Old (No Children) (Young } \\
\text { Females) }\end{array}$ \\
\hline 6 & Working Older Couples (No Children) (Empty Nesters) \\
\hline 7 & Working Single Males Over 40 Years Old (No Children) (Mid-Age Males) \\
\hline 8 & $\begin{array}{l}\text { Working Single Females Over 40 Years Old (No Children) (Mid-Age } \\
\text { Females) }\end{array}$ \\
\hline 9 & Retired Couples (No Children) (Retired Couples) \\
\hline 10 & Retired Single Females (No Children) (Widows) \\
\hline 11 & Retired Single Men (No Children) (Widowers) \\
\hline
\end{tabular}



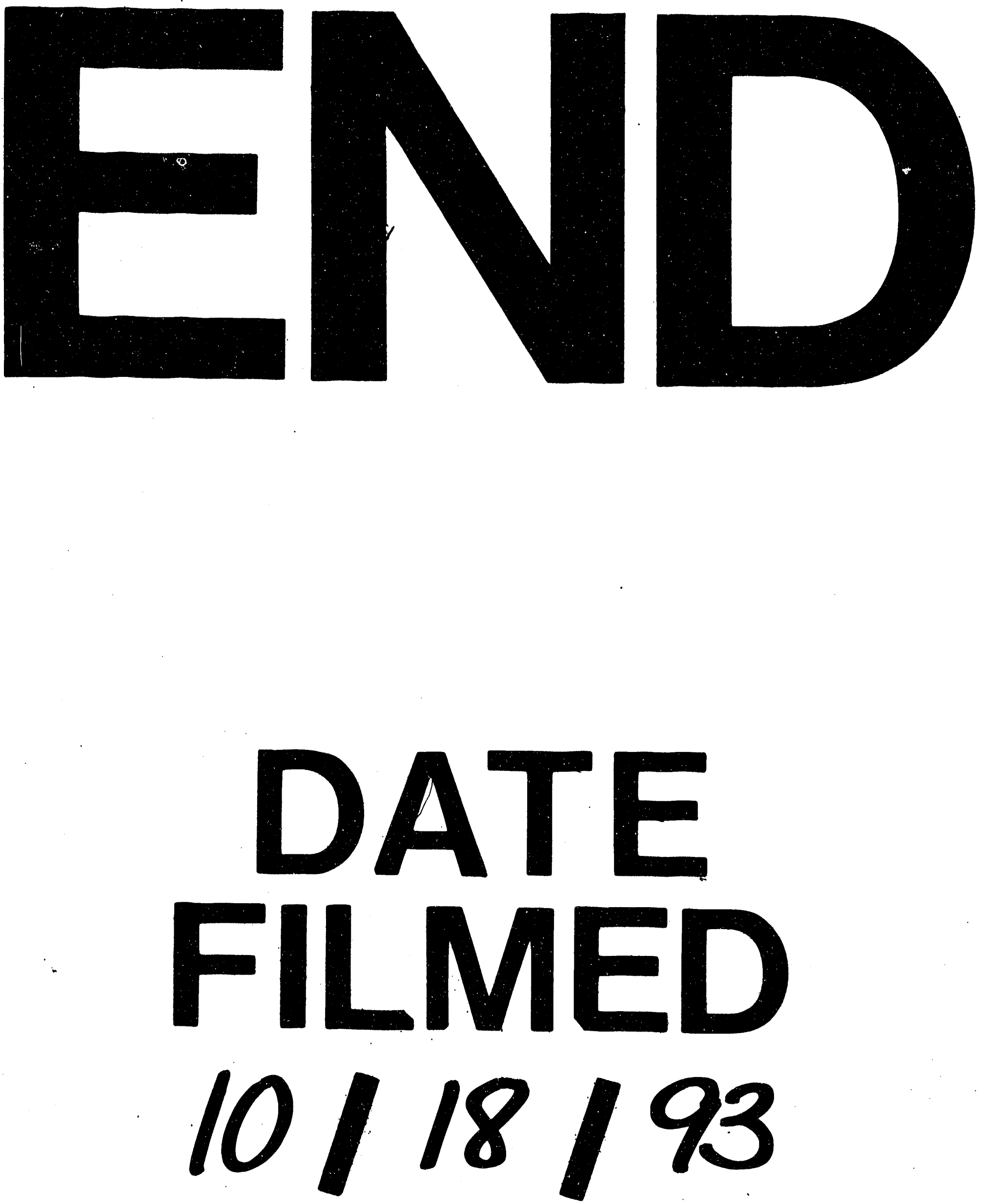
